\title{
Electrochemical measurements bearing on the oxidation state of the Skaergaard Layered Intrusion
}

\author{
Annie B. Kersting ${ }^{1}$, Richard J. Arculus ${ }^{1}$, John W. Delano ${ }^{2}$, and Daniel Loureiro ${ }^{3}$ \\ ${ }^{1}$ Department of Geological Sciences University of Michigan, Ann Arbor, MI 48109, USA \\ ${ }^{2}$ Department of Earth Sciences State University of New York at Albany, Albany, NY 12222, USA \\ ${ }^{3}$ Escuela de Geologia, Minas y Geofisica Facultad de Ingenieria Universidad Central de Venezuela Caracas, Venezuela
}

\begin{abstract}
The oxygen fugacities $\left(f \mathrm{O}_{2}\right.$ 's) of magnetically-concentrated fractions (MCF) of three rock samples from the Skaergaard Layered Intrusion were measured between $800-1150^{\circ} \mathrm{C}$ using oxygen-specific, solid zirconia electrolytes at atmospheric pressure. Two of the bulk rock samples (an oxide cumulate and an oxide-bearing gabbro) are from the Middle Zone (MZ) and the other (an olivine plagioclase orthocumulate) is from the Lower Zone (LZ). All MCF define $f \mathrm{O}_{2}$ versus $T$ arrays that lie 1.5-0.5 log units above the fayalite-magnetite-quartz (FMQ) buffer. Experiments with different cell-imposed initial redox states (one from a reduced direction and one from an oxidized direction) were run on each sample in an attempt to achieve experimental reversibility. This was accomplished by imposing a known redox memory on the galvanic cell prior to loading each sample. Reversibility for each sample agreed to better than 0.2 of a $\log$ unit. Irreversible autoreduction of 0.2 of a log unit was observed on the two MZ samples at temperatures exceeding $1065^{\circ} \mathrm{C}$. Scanning electron microscope and electron microprobe study of pre- and post-run products shows that reaction and textural re-equilibration occurred among the oxide phase assemblages under the experimental conditions employed. Careful characterization of pre- and post-run assemblages is clearly necessary before adequate interpretation of the experimental results can be made in these types of electrochemical studies. Different approaches to investigations of the $\mathrm{fO}_{2}$ of the Skaergaard Intrusion, be it thermodynamic calculations or experimental methods, should yield concordant results or at least understandable discrepancies. Calculated $f_{2}$ 's using thermobarometry applied to the ilmenite-magnetite pairs in the post-experimental assemblages agree with the experimentally determined $f \mathrm{O}_{2}$ 's to within one $\log$ unit at a given temperature. These results are also consistent with previously calculated $f \mathrm{O}_{2}$ values (Buddington and Lindsley 1964; Morse et al. 1980), but are considerably more oxidized than a previous electrolyte-based $f \mathrm{O}_{2}$ study of a different sample suite from the Skaergaard (Sato and Valenza 1980) that include values close to the iron-wustite (IW) buffer from both MZ and LZ oxide separates. Differences between this electrochemical study and that of Sato and Valenza (1980) may be due to variations in the level of indigenous (or curatorially-introduced) carbon in the samples studied. Despite a number of experimental difficulties, electrochemical cells can provide an accurate and precise
\end{abstract}

Offprint requests to: A.B. Kersting method of determining the oxygen fugacity of naturally occurring, complex oxide assemblages. Tight experimental reversals and reproducible values obtained in heating and cooling cycles are an indication of the precision and accuracy of the data recoverable with electrochemical cells.

\section{Introduction}

The properties of stabilized-zirconia solid electrolytes for use as high-temperature, oxygen concentration cells were first systematically investigated by Kiukkola and Wagner (1957). Geological applications were pioneered by Sato (1971) and have since become an important method for thermodynamic studies of geological materials at high temperatures (e.g. Sato 1971; Arculus and Delano 1981; Ulmer et al. 1987; O'Neill 1987; Mattioli and Wood 1988; Virgo et al. 1988).

Zirconia electrolytes offer a potential advantage over calculations using thermochemical data and solution models because there are (a) fewer assumptions involved due to the direct nature of the measurement and (b) modern voltmeters offer the potential for accurate and precise results (Holmes et al. 1986). However, due to some apparent discrepancies that have developed between electrochemically-measured and thermodynamically-calculated $f \mathrm{O}_{2}$ 's on similar, but not identical, geologic samples (e.g. Arculus 1985; O'Neill and Wall 1987), it seemed to us that a direct comparison of results obtained using these different approaches with the same well-constrained assemblages would be worthwhile.

In addition to exploring the capability of electrochemical cells for determination of the $f \mathrm{O}_{2}$ of natural samples, measurements were undertaken in part to resolve the existing disparity between previously measured and calculated $f \mathrm{O}_{2}$ values for the Skaergaard Intrusion. Sato and Valenza (1980) used solid electrolytes to determine $f \mathrm{O}_{2}$ as a function of $T$ for MZ and LZ oxide separates, obtaining values between wustite-magnetite (WM) and below iron-wustite (IW) (Fig. 1). In contrast, Morse et al. (1980) used the compositions of coexisting iron-titanium oxides to calculate $\mathrm{MZ}$ values and extrapolated using calculated liquid compositions to estimate $\mathrm{LZ} f \mathrm{O}_{2}$ versus $T$ arrays; both methods yield results close to the fayalite-magnetite-quartz (FMQ) buffer at high temperatures (Fig. 1 and Table 1). In this paper, we compare electrochemically-measured and thermodynamically-calculated $f_{2}$ 's using the same assem- 


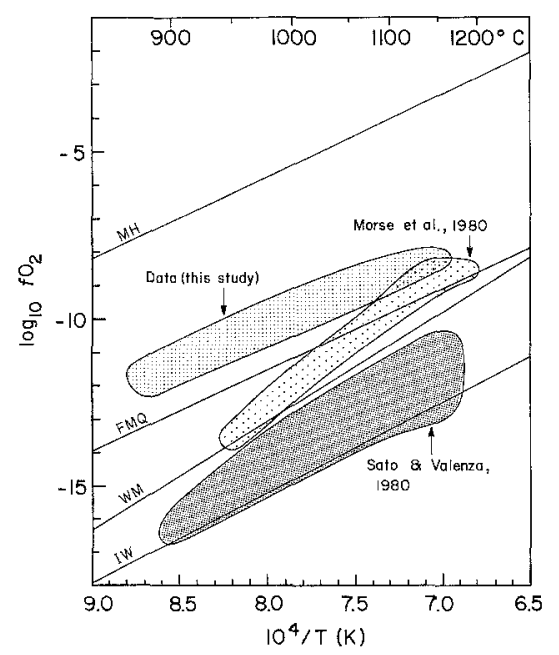

Fig. 1. Compilation of $\mathrm{fO}_{2}-T$ determinations for the Skaergaard Middle and Lower Zones from this study, Morse et al. (1980), and Sato and Valenza (1980) between $850^{\circ}-1200^{\circ} \mathrm{C}$. The magnetite-hematite $(M H)$, fayalite-magnetite-quartz $(F M Q)$, wustitemagnetite $(W M)$, and iron-wustite $(I W)$ represent synthetic buffers determined by Eugster and Wones (1962), O'Neill (1987), Eugster and Wones (1962), and Darken and Gurry (1945), respectively

blages, but emphasize that the separates employed were not aliquots of the samples used by Sato and Valenza (1980).

It is important to define the nature of and controls on redox states of mafic magmas in order to understand better the chemical evolution of magmatic systems. The redox state of iron in a magma reflects the nature of the melting process in source regions, the history of fractionation and magma-wallrock interaction, and volatile losses (if any) from the magma. Measurements of the variation in $f \mathrm{O}_{2}$ generated during crystallization of a mafic magma at shallow depths in the Earth's crust can place constraints on the chemical and thermal balance prevailing during differentiation (Ghiorso 1985; Ghiorso and Carmichael 1985).

\section{Skaergaard mineralogy}

In this study, the redox state of samples from the Skaergaard Layered Intrusion have been examined through the use of electrochemical cells. The Skaergaard, which is located in East Greenland, is an Eocene gabbroic layered intrusion that has undergone extreme differentiation. First studied in detail by Wager and Deer (1939), it has become one of the most thoroughly studied igneous bodies and remains one of the best documented occurrences of a fraction- ally crystallized magma (Hunter and Sparks 1987). To a first approximation, the Skaergaard appears to represent a single magmatic pulse that crystallized at pressures estimated at $1.2 \mathrm{kbar}$ at the base of the Lower Zone (McBirney 1975). The Layered Series which represents approximately $78 \%$ of the intrusion (Taylor and Forester 1979) is composed of the Lower Zone (LZ), Middle Zone (MZ), and Upper Zone (UZ).

The two MZ and one LZ samples used in this study are from the collection of Wager and Brown (1967). MZ sample (4359) is an oxide cumulate consisting of $99 \%$ oxides located $1120 \mathrm{~m}$ from the exposed base of the intrusion. MZ sample (4371) is a plagioclase-pyroxene-oxide gabbro located $1000 \mathrm{~m}$ from the exposed base. The third sample LZ (5107), located $100 \mathrm{~m}$ above the exposed base of the intrusion, is a plagioclase-olivine orthocumulate with pyroxene and oxides as intercumulus phases (Wager and Brown 1967, Fig. 33, p. 62). The mineral baddeleyite $\left(\mathrm{ZrO}_{2}\right)$, which has not been previously reported from the Skaergaard, is present inside several ilmenite grains in LZ sample (5107), and may represent exsolution from the host ilmenite during cooling (Keil and Fricker 1974).

For the purpose of this study, magnetically concentrated MZ and LZ fractions were used. All three fractions consisted of coexisting Fe-Ti oxides, and hence, were well buffered assemblages.

\section{Electrochemical theory}

Although the precise configuration of oxygen-specific solid electrolyte cells employed in electrochemical studies has been variable, the basic principle is the same. When differences in oxygen potential (equivalent to $\mathrm{fO}_{2}$ ) exist at opposing ends of an electrolyte, an emf is generated due to the flow of oxygen ions from the high-tolow potential electrode according to the Nernst equation:

$E=\frac{R T}{4 F} \ln \left[\frac{f\left(\mathrm{O}_{2}\right) \text { (sample) }}{f\left(\mathrm{O}_{2}\right) \text { (reference) }}\right]$

where $E$ is the emf in $\mathrm{mV}, T$ is the temperature in degrees Kelvin, $R$ and $F$ are the gas and Faraday constants, respectively. The factor 4 represents the number of electrons involved in the cell reaction $\left(\mathrm{O}_{2}=2 \mathrm{O}^{2-}\right)$. The electrical potential across the cell (emf) is a measure of the difference in the chemical potential $\left(f \mathrm{O}_{2}\right)$ between the two electrodes. If the temperature and the $f \mathrm{O}_{2}$ of one side of the electrode (e.g. reference) are known, the $\mathrm{fO}_{2}$ of the other (e.g. sample) can be determined by measuring the emf across the cell.

The emf represents the actual difference in oxygen potential across the cell if-and-only-if the measured voltage is purely the result of ionic conduction; efforts are made in consequence to minimize the effects of electronic conduction and ionic diffusion. Fortunately, the $f \mathrm{O}_{2}-T$ range in which $\mathrm{Y}_{2} \mathrm{O}_{3}$ (or $\mathrm{CaO}$ )-stabilized $\mathrm{ZrO}_{2}$ acts as essentially a pure $\mathrm{O}^{2-}$ conductor is well known and encompasses geologically relevant conditions (Sato 1971). Migration of $\mathrm{O}^{2-}$ through the $\mathrm{ZrO}_{2}$ electrolyte and alteration of the $\mathrm{O}_{2}$ potential of the electrode can be minimized by the use of a high impedance voltmeter in the emf circuit.

Table 1. Comparison of calculated $\mathrm{fO}_{2}-T$ values for the Skaergaard Middle and Lower Zones from various workers. All values plot within $0.5 \log$ unit from FMQ. Location of each rock sample is given in meters from the exposed base of the intrusion Compilation of derived $T-f \mathrm{O}_{2}$ values from Skaergaard coexisting Ilm - Mt pairs

\begin{tabular}{|c|c|c|c|c|c|c|}
\hline Worker & Location (m) & Sample \# & $10^{4} / T(\mathrm{~K})$ & Temp (C) & $\log f \mathrm{O}_{2}$ & $\log f \mathrm{O}_{2}-\mathrm{FMQ} *$ \\
\hline Morse et al. (1980) & $\begin{array}{c}1150 \mathrm{MZ} \\
700 \mathrm{LZ}\end{array}$ & $\begin{array}{l}3661 \\
2308\end{array}$ & $\begin{array}{l}7.08 \\
6.88\end{array}$ & $\begin{array}{l}1139 \\
1180\end{array}$ & $\begin{array}{l}-8.75 \\
-8.65\end{array}$ & $\begin{array}{l}+0.40 \\
-0.01\end{array}$ \\
\hline $\begin{array}{l}\text { Buddington and Lindsley } \\
\text { (1964) }\end{array}$ & $\begin{array}{c}1150 \mathrm{MZ} \\
700 \mathrm{LZ}\end{array}$ & $\begin{array}{l}3661 \\
2308\end{array}$ & $\begin{array}{l}8.90 \\
8.74\end{array}$ & $\begin{array}{l}850 \\
871\end{array}$ & $\begin{array}{l}-13.70 \\
-13.70\end{array}$ & $\begin{array}{l}+0.01 \\
-0.39\end{array}$ \\
\hline $\begin{array}{l}\text { This paper RP (using } \\
\text { Buddington and Lindsley } \\
{[1964] \text { ) }}\end{array}$ & $\begin{array}{c}1120 \mathrm{MZ} \\
1000 \mathrm{MZ} \\
100 \mathrm{LZ}\end{array}$ & $\begin{array}{l}4359 \\
4371 \\
5107\end{array}$ & $\begin{array}{l}7.39 \\
7.42 \\
7.53\end{array}$ & $\begin{array}{l}1080 \\
1075 \\
1055\end{array}$ & $\begin{array}{r}-9.40 \\
-9.50 \\
-10.00\end{array}$ & $\begin{array}{l}+0.54 \\
+0.51 \\
+0.29\end{array}$ \\
\hline
\end{tabular}

* FMQ from O’Neill (1987) 


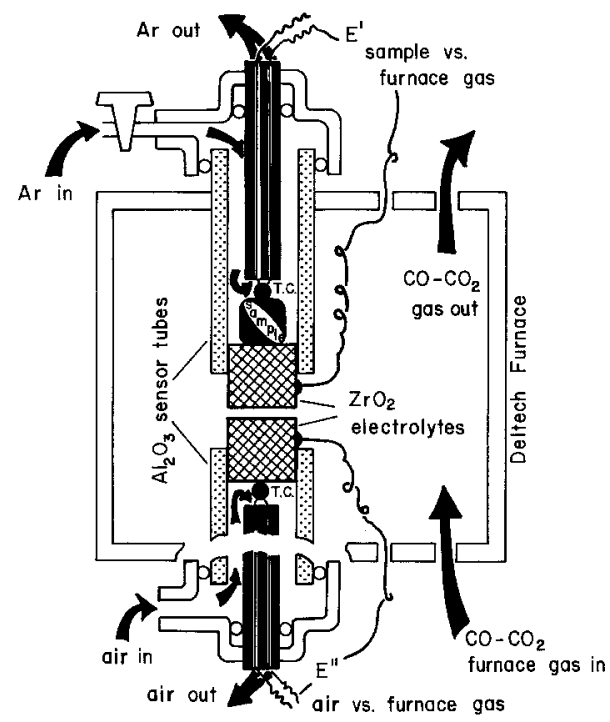

Fig. 2. Schematic diagram of the experimental apparatus modified from Arculus and Delano (1981). E' represents the emf generated by the difference in $\mathrm{O}_{2}$ potential between the sample unknown and the $\mathrm{CO}-\mathrm{CO}_{2}$ furnace gas. $E$ " represents the emf generated by the difference in $\mathrm{O}_{2}$ potential between the known reference gas (air) and the $\mathrm{CO}-\mathrm{CO}_{2}$ furnace gas. T.C. = thermocouple

\section{Specific instrument design}

The experimental apparatus used in the present study (Fig. 2) is a slight modification of the basic double cell configuration originally designed by Sato (1971) and employed by Sato and Valenza (1980). The apparatus consisted of two stabilized zirconia solid electrolytes manufactured under license from CSIRO of Australia by Ceramic Oxide Fabricators Pty Ltd, under the name of "SIRO sensors". The $\mathrm{SIRO}_{2}$ sensor is a solid yittria-stabilized $\mathrm{ZrO}_{2}$ plug that is permanently bonded via a high-temperature, eutectic weld $\left(\mathrm{Al}_{2} \mathrm{O}_{3}-\mathrm{ZrO}_{2} \mathrm{mix}\right)$ to a high-purity alumina sensor tube. These electrolytes are placed inside a sealed large bore alumina tube within a Deltech (DT-31-Vt) furnace. One cell (reference) measures the difference in chemical potential of $\mathrm{O}_{2}$ between a furnace gas outside the cell, and a reference gas (air) that is pumped inside. The second cell (sample) measures the difference in $\mathrm{O}_{2}$ potential between the furnace gas $\left(\mathrm{OO}_{2}\right.$ calculated knowing the $\mathrm{fO}_{2}$ of the reference gas and monitoring the emf of the reference cell) and the Skaergaard sample within the cell. Thus, in this type of experimental configuration, the $\mathrm{fO}_{2}$ of the geologic sample is measured against a known external gas electrode. $\mathrm{A} \mathrm{CO}-\mathrm{CO}_{2}$ gas mixture was used as the outside furnace gas. Temperature was measured with a calibrated $\mathrm{Pt}-\mathrm{Pt}_{87} \mathrm{Rh}_{13}$ thermocouple, the $\mathrm{Pt}$ leg of which also served as the internal emf lead for the electrolyte. The external lead was connected to a high impedance $\left(10^{15} \mathrm{Ohm}\right)$ electrometer. The sample was placed in a closed-end Fe-saturated $\mathrm{Pt}$ capsule (previously heated to $1100^{\circ} \mathrm{C}$ with $\mathrm{Fe}_{0.947} \mathrm{O}$ for $1 \mathrm{~h}$ ). This capsule was placed into the cell in contact with the $\mathrm{ZrO}_{2}$ electrolyte and the Pt lead of the thermocouple.

This experimental design minimizes the potential problem of voltage instability that may result from a variety of causes, including oxygen exchange between the sample and the reference gas, poor electrical contacts, thermal gradients across the cell, residual gas inside the sample container, or reaction between the sample and its container. Oxygen exchange is minimized by adjusting the reference gas mixture to minimize the potential across the cell. Temperature profiling of the Deltech furnace has shown that the center of the hot spot is only about $10 \mathrm{~mm}$ wide and that the hot spot migrates with changes in temperature by approximately $18 \mathrm{~mm}$ in the range between $527^{\circ}$ and $1327^{\circ} \mathrm{C}$ (Holmes et al. 1986). The effects of thermal gradients across the cell are minimized by reducing the distance between the two electrolytes. The double cell configuration allows the two electrolytes to be placed within $10 \mathrm{~mm}$ of each other, while the thermocouple was located about 2-3 $\mathrm{mm}$ from the geologic sample.

\section{Experimental procedure}

To minimize possible contamination, several precautions were taken during sample preparation including gentle hand grinding of the sample in an agate mortar, magnetically hand separating the grains of interest, and examination of the grain surfaces under a microscope for signs of secondary oxidation. No chemical reagents were used during sample preparation. Nevertheless, it is clear from experience with carbon isotope studies of igneous rocks that atmospheric $\mathrm{CO}_{2}$ (organic derived) can be adsorbed by fresh surfaces, and may pose experimental difficulties (Des Marais and Moore 1984). Approximately 100-120 milligrams of sample was used for each experimental run.

To ensure that the measured $f \mathrm{O}_{2}$ represents an equilibrium value, and that the apparatus is functioning properly, a four-step experimental procedure is carried out to test thermal reproducibility, reversibility of the $f \mathrm{O}_{2}$ data, and monitor voltage stability. For all experiments, voltage emf was stable to within one millivolt at each temperature for one hour before equilibrium was assumed.

Although an extra high purity grade $\mathrm{Al}_{2} \mathrm{O}_{3}$ tube is now available, the $\mathrm{Al}_{2} \mathrm{O}_{3}$ tubes of the cells used in the present study contain about $450 \mathrm{ppm}$ of $\mathrm{Fe}+\mathrm{Ti}$ (Loureiro et al. 1989). An experimental strategy to exploit this weak "redox cell memory" was employed. The experimental procedure involves four separate steps. (1) A sample of iron + wustite (IW) is loaded into the cell and run at high temperatures to test the performance of the apparatus against a redox standard and to impose a weak, IW memory on the sensor. Experimental determination of the position of the IW buffer in $f \mathrm{O}_{2}-T$ space is a direct monitor of the Nernstian performance of the cell when compared with a well-determined buffer. (2) A geologic sample is loaded into the sensor possessing the IW memory at room temperature. Upon heating, the sample quickly overrides the IW memory (within minutes) and approaches its equilibrium redox state from a reduced direction. The sample is cycled up and down temperature between $850^{\circ}-1150^{\circ} \mathrm{C}$ while the emf is measured at a number of representative temperatures. In a further test of $f \mathrm{O}_{2}$ reproducibility, the sample-bearing cell is pulled from the furnace, cooled, opened, flushed with fresh Ar, and resealed. The "purged" sample is plunged into a hot furnace and measured at a single temperature. This is the last temperature the sample is subjected to before being finally pulled from the furnace. (3) The sensor is emptied of its sample and baked at $1000^{\circ} \mathrm{C}$ in air to remove any vestige of memory from the previous experiment. The empty sensor is sealed and monitored for drift in the emf. This "blank run" is designed to check the mechanical integrity of the apparatus. (4) A fresh aliquot of the same geological sample used in step 2 is loaded into the sensor at room temperature. Upon heating, the sample approaches its equilibrium redox state from an oxidized direction. After temperature cycling the sample is flushed with fresh Ar and measured at a single temperature. The advantage of this four-step procedure is that the $\mathrm{fO}_{2}$ of the sample can be approached from the oxidized and reduced sides of the steady state value, thus achieving reversed equilibrium. In all instances, the void-space within the sensor is filled with Ar prior to sealing. In steps 1,2 , and 4 , the initial Ar has a measured $\log$ $f \mathrm{O}_{2}=-3$ at $1030^{\circ} \mathrm{C}$. For additional details of the experimental procedures, refer to Loureiro et al. (1989).

\section{Experimental results}

Five samples of IW were run (step 1) during a period of two months. Our data define a reproducible univariant line (Fig. 3): $\log f \mathrm{O}_{2}=(-27510 / T)+6.75 ; r=0.9997 ; T$ in Kelvin. Representative results from our experiments are compared to previously determined IW values (Darken and Gurry 1945; Holmes et al. 1986) in Fig. 3. Good agreement 


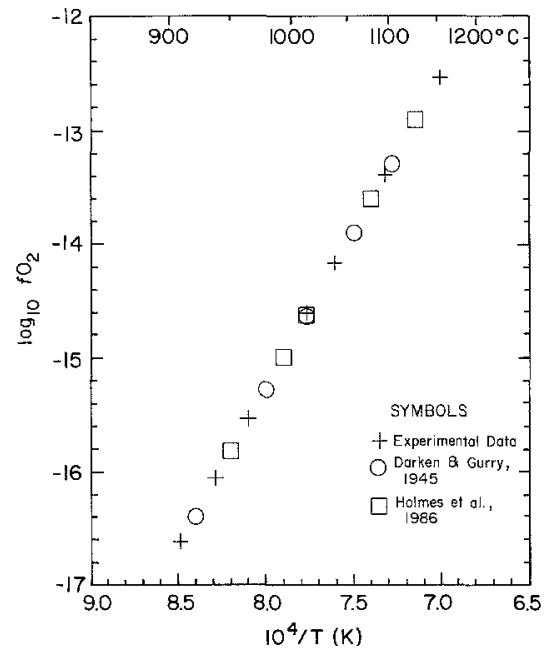

Fig. 3. Measured $\mathrm{fO}_{2}$ : Iron-Wustite. Comparison between this study (experimental data) and previous results from Darken and Gurry (1945) and Holmes et al. (1986). Data points for Darken and Gurry and Holmes et al. were calculated at different temperatures to improve the clarity of the graph by avoiding overlaps in our data-set. At $T=1017^{\circ} \mathrm{C}$ all three experimentally determined IW $f \mathrm{O}_{2}-T$ values were plotted to demonstrate that the values from this study are in good agreement with other workers

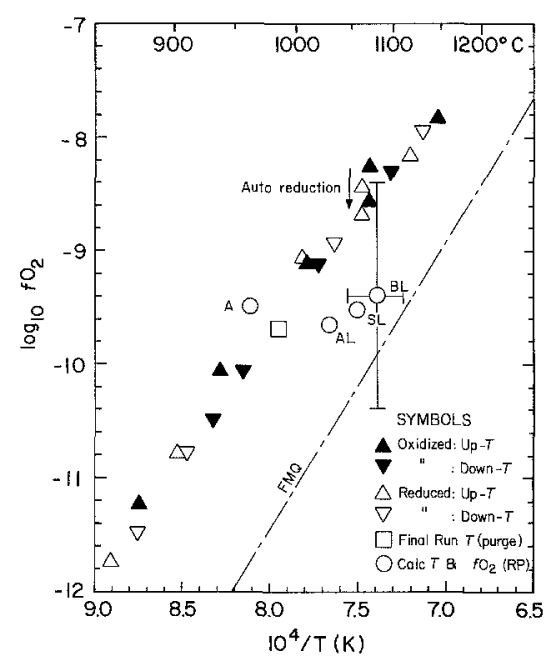

Fig. 4. Measured $f \mathrm{O}_{2}$ : Middle Zone cumulate (4359). Selected data points are shown for both the reduced direction (step 2) and the oxidized direction (step 4). A subset of the experimental data set was used to retain clarity. A complete table of experimental run values is listed in appendix A. The FMQ buffer of O'Neill (1987) is drawn for reference. Autoreduction on the order of 0.2 of a $\log$ unit is observed in both the oxidized and reduced runs at approximately $1070^{\circ} \mathrm{C}$. The reduced and oxidized runs agree to 0.1 of a $\log$ unit. The square symbol represents the $\mathrm{fO}_{2}$ of the purge run. The circles represent calculated $f \mathrm{O}_{2}-T$ values for the RP using the thermometers of Buddington and Lindsley $(B L)(1964)$, Anderson and Lindsley $(A L)$ (1988), Spencer and Lindsley $(S L)$ (1981), and Anovitz et al. (A) (1985). Error bars for the BL thermometer are drawn

between this study and those reported by other investigators suggests that the experimental accuracy is high and the performance of the $\mathrm{SIRO}_{2}$ cells is strictly Nernstian in this temperature range.

$\mathrm{MZ}$ oxide cumulate (4359), plots $1.5 \log$ units above the FMQ buffer between $790^{\circ}$ and $1150^{\circ} \mathrm{C}$ (Fig. 4). Vir-

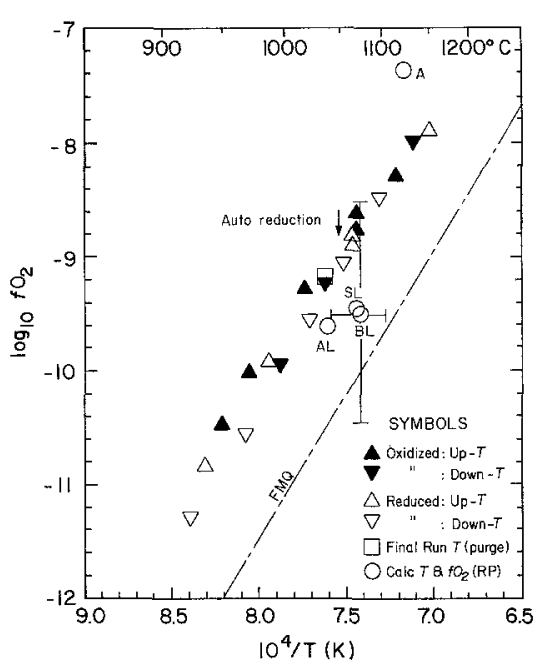

Fig. 5. Measured $f \mathrm{O}_{2}$ : Middle Zone (4371). Autoreduction on the order of 0.2 of a $\log$ unit is observed in both the oxidized and reduced runs at approximately $1070^{\circ} \mathrm{C}$. The reduced and oxidized runs agree to 0.1 of a $\log$ unit. See Fig. 4 for further description

tually identical behavior was observed for both the reduced (step 2) and oxidized (step 4) runs on different aliquots of this sample. The sample stabilized in two hours at $790^{\circ} \mathrm{C}$. Between $1065^{\circ}$ and $1070^{\circ} \mathrm{C}$, both aliquots of sample showed signs of irreversible autoreduction of about 0.2 of a $\log$ unit. After several hours, the emf signal stabilized and no further reduction was observed. The sample was taken up to higher temperatures and then cycled back down. The purge value plots on the reduced slope. The remaining $f \mathrm{O}_{2}$ measurements define a new slope, 0.2 of a $\log$ unit more reduced than the initial measurements, represented by the linear regression: $\log f \mathrm{O}_{2}=(-21835 / T)+$ $7.63, r=0.9993$ (reduced direction) and $\log f \mathrm{O}_{2}=(-21034 /$ $T)+7.05, r=0.9994$ (oxidized direction). The results from each direction agree to within 0.1 of a $\log$ unit, further supporting the claim that equilibrium was achieved.

MZ sample (4371), consisting of the magnetic fraction of the gabbroic rock, plots $1.0 \mathrm{log}$ unit above FMQ measured between $900-1150^{\circ} \mathrm{C}$ (Fig. 5). Results between the reduced and oxidized runs differ by 0.1 of a $\log$ unit. This sample was slower to equilibrate than MZ cumulate (4359). The oxidized run was begun at the higher temperature of $946^{\circ} \mathrm{C}$ in hopes of avoiding sluggish equilibration. The sample began to autoreduce at $1070^{\circ} \mathrm{C}$ during both the oxidized and reduced runs. In a similar manner to $\mathrm{MZ}$ cumulate (4359), the magnitude of the reduction was about 0.2 of a $\log$ unit, and no further reduction was observed after stabilization. The remaining measurements define a line that is 0.2 of a $\log$ unit more reduced than that obtained prior to the autoreduction. The linear regression for the reduced direction (after reduction) is $\log f \mathrm{O}_{2}=(-26046 /$ T) $+10.50, r=0.9993$ and for the oxidized direction (after reduction) is $\log f \mathrm{O}_{2}=(-24576 / T)+9.50, r=0.9993$. Attainment of equilibrium during the purge was slower than in the previous MZ experiment (4359), although the final stable emf value measured from both purge experiments plot on the reduced slope.

The third sample consisted of the magnetic fraction of LZ gabbro (5107) and is the most reduced of the three samples. Although the concentrated sample contained predominantly $\mathrm{Fe}-\mathrm{Ti}$ oxides, minor plagioclase + olivine + py- 


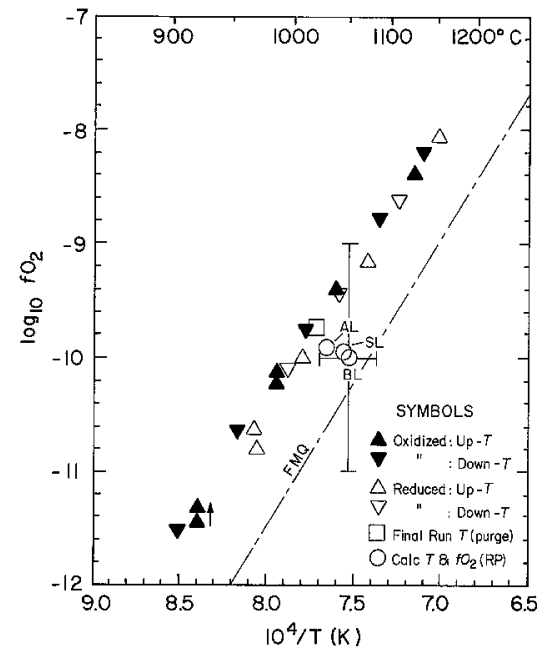

Fig. 6. Measured $f \mathrm{O}_{2}$ : Lower Zone (5107). Sample was slow to equilibrate as noted by the oxidized drift in the low temperature measurements. Stable emf readings did not occur until $970^{\circ} \mathrm{C}$. No autoreduction was observed for this rock sample. The reduced and oxidized runs agree to 0.1 of a $\log$ unit. See Fig. 4 for further description

roxene were also present in the aliquot. LZ (5107) equilibrated at about $0.8 \mathrm{log}$ units above $F M Q$ between 900-1150 $\mathrm{C}$ (Fig. 6). At low temperatures this sample was the most sluggish, stabilizing seventeen hours later at $970^{\circ} \mathrm{C}$. This behavior was observed during both the oxidized and reduced runs. In contrast to the two MZ samples, the LZ sample did not autoreduce at high temperature (Fig. 6). The linear regression for the reduced direction (once equilibrium was attained) is $\log f \mathrm{O}_{2}=(-23884 / T)+$ $8.67 r=0.9994$ and from the oxidized direction $\log f \mathrm{O}_{2}=$ $(-23309 / T)+8.35 r=0.9995$. The reduced and oxidized values agree to within 0.1 of a log unit.

A second LZ gabbro sample (4392) (Table 7; Figs. 19 and $21 \mathrm{a}$ of Wager and Brown 1967) was investigated. It consisted of approximately $50 \%$ plagioclase, $20 \%$ olivine, $20 \%$ pyroxene, and $10 \% \mathrm{Fe}-\mathrm{Ti}$ oxides. The sample behaved erratically for 81 hours never reaching equilibrium and has not been subjected to further experimental study.

\section{Discussion of experimental results}

Reversibility has been demonstrated by performing two experiments with different initial cell-imposed redox states on separate aliquots of the same rock sample. Thus, the sample is allowed to approach equilibrium from both an oxidized and reduced cell-imposed redox environment. An $\mathrm{fO}_{2}$ difference of 11 orders of magnitude at $1030^{\circ} \mathrm{C}$ is represented by the initial cell-imposed conditions between test 2 (reduced direction) and test 4 (oxidized direction). In all three samples from the Skaergaard, the emf values measured from the reduced and oxidized directions (steps 2 and 4) agree to better than 0.1 of a $\log$ unit (Figs. 4, 5, 6), and indicate that the initial cell-imposed conditions do not appear to contribute to the final measured redox states of the samples. Good agreement between runs 2 and 4 for each Skaergaard sample suggests the recorded steady state value represents an equilibrium measurement.
Reproducible emf values measured during temperature cycling and purge procedures indicate that the sample is capable of reaching reproducible equilibrium $\mathrm{fO}_{2}$ values during both upward and downward limits of a given temperature cycle. The return to previously measured $\mathrm{fO}_{2}$ values after flushing the system with Ar (purge) suggests that the sample is capable of buffering a fresh aliquot of Ar inside the cell at the previous $f \mathrm{O}_{2}$.

Autoreduction has been previously observed in other high temperature intrinsic $\mathrm{fO}_{2}$ measurements (Sato and Valenza 1980; Ulmer et al. 1987). It has been suggested (Sato 1976) that high temperature sample autoreduction occurs due to reaction involving trace carbon (metastable at 1 bar) within the sample. At high temperatures, the carbon is postulated to react with $\mathrm{O}_{2}$ in the sample or cell atmosphere (forming $\mathrm{CO}$ and $\mathrm{CO}_{2}$ ) resulting in a reduction of the sample. A synthetic low- $\mathrm{Fe}^{3+}$ basaltic glass spiked with synthetic graphite showed irreversible autoreduction at high temperatures in an electrochemical experiment demonstrating that carbon can act as a potential reducing agent if it is present in the geologic sample (Sato 1979; Ulmer et al. 1987).

It is clear that if autoreduction is the result of high temperature vaporization of carbon, changes in the measured emf must reflect a reaction between (a) the oxygenbearing Ar gas filling the cell and (b) the sample that results in a new emf signal dominated by the (now) reduced sample. The ability of the sample to return to the new reduced equilibrium from the Ar purge demonstrates that the gas component is not contributing to the reduction of these samples.

Other possible explanations that have been advanced for the cause of autoreduction are the presence of reducing contaminants such as decrepitation and dissociation of abundant $\mathrm{CO}_{2}$ fluid inclusions (Ulmer et al. 1987) and hydrogen contamination resulting from diffusion of a $\mathrm{H}_{2}-$ bearing furnace gas through the cell walls (Elliot et al. 1982). Due to the absence of both optically apparent fluid inclusions in the oxide phases and $\mathrm{H}_{2}$ used as the furnace gas, these possibilities seem an unlikely explanation for the autoreduction observed in the Skaergaard MZ samples.

Previously reported high temperature autoreduction has been significantly greater than the $0.2 \mathrm{log}$ units observed in this study. For example, Sato and Valenza (1980) reported autoreduction of their Skaergaard samples on the order of $2 \log$ units at temperatures near $1100^{\circ} \mathrm{C}$. Ulmer et al. (1987) reported autoreduction from a San Carlos olivine on the order of $1.5 \log$ units $f \mathrm{O}_{2}$ near $900^{\circ} \mathrm{C}$.

Selection of the "true" $f \mathrm{O}_{2}$ as indicated by the initial measurements at lower temperature or the later measurements after autoreduction remains uncertain (Ulmer et al. 1987). In our experiments, choosing between the oxidized and reduced univariant curves from each $\mathrm{MZ}$ sample represents a minor difference of only 0.2 of a log unit. Regardless of which $f \mathrm{O}_{2}-T$ curve is chosen (before or after autoreduction), both MZ samples plot about 1.5-1.0 log units above FMQ. The cause of the high temperature autoreduction of the two MZ samples remains uncertain.

In contrast to the two $\mathrm{MZ}$ samples, no autoreduction was observed for LZ (5107) that plots $0.8 \log$ unit above FMQ. Since all three samples were subjected to the same experimental procedure, it would appear that the cause of the autoreduction in the two $\mathrm{MZ}$ samples is independent of the procedure. 
Table 2. Representative microprobe analyses: Middle Zone \#4359

\begin{tabular}{|c|c|c|c|c|c|c|}
\hline & \multicolumn{3}{|c|}{ Natural sample } & \multicolumn{3}{|c|}{ Run products } \\
\hline & $\mathrm{Ilm}$ & Usp-Mt & $\mathrm{Mt}$ & $\mathrm{Ilm}$ & $\mathrm{Mt}$ & Psb \\
\hline \multicolumn{7}{|c|}{ Oxide Wt \% } \\
\hline $\mathrm{SiO}_{2}$ & 0.02 & 0.03 & 0.02 & 0.01 & 0.08 & 0.00 \\
\hline $\mathrm{TiO}_{2}$ & 52.27 & 18.20 & 0.99 & 45.57 & 17.79 & 59.78 \\
\hline $\mathrm{Al}_{2} \mathrm{O}_{3}$ & 0.00 & 3.83 & 0.30 & 0.26 & 3.20 & 0.48 \\
\hline $\mathrm{Cr}_{2} \mathrm{O}_{3}$ & 0.02 & 0.06 & 0.00 & 0.01 & 0.02 & 0.03 \\
\hline $\mathrm{V}_{2} \mathrm{O}_{3}$ & 0.21 & 1.63 & 0.56 & 0.37 & 1.33 & 0.33 \\
\hline $\mathrm{Fe}_{2} \mathrm{O}_{3}$ & 1.87 & 28.18 & 66.07 & 14.32 & 30.20 & 19.24 \\
\hline $\mathrm{FeO}$ & 41.91 & 45.91 & 31.97 & 35.21 & 43.31 & 16.36 \\
\hline $\mathrm{MnO}$ & 0.55 & 0.17 & 0.00 & 0.50 & 0.46 & 0.15 \\
\hline $\mathrm{MgO}$ & 2.56 & 1.61 & 0.03 & 2.94 & 2.75 & 3.24 \\
\hline $\mathrm{CaO}$ & 0.00 & 0.00 & 0.02 & 0.02 & 0.00 & 0.00 \\
\hline Total & 99.41 & 99.62 & 99.96 & 99.21 & 99.14 & 99.61 \\
\hline $\mathrm{FeO}^{*}$ & 43.60 & 71.26 & 91.42 & 48.10 & 70.49 & 33.67 \\
\hline \multicolumn{7}{|c|}{ Mole percent } \\
\hline $\mathrm{Si}$ & 0.000 & 0.001 & 0.001 & 0.000 & 0.003 & 0.000 \\
\hline $\mathrm{Ti}$ & 0.980 & 0.502 & 0.029 & 0.857 & 0.491 & 1.709 \\
\hline Al & 0.000 & 0.166 & 0.013 & 0.008 & 0.138 & 0.022 \\
\hline $\mathrm{Cr}$ & 0.000 & 0.002 & 0.000 & 0.000 & 0.000 & 0.000 \\
\hline $\mathrm{V}^{3+}$ & 0.004 & 0.048 & 0.017 & 0.007 & 0.039 & 0.010 \\
\hline $\mathrm{Fe}^{3+}$ & 0.035 & 0.778 & 1.910 & 0.270 & 0.834 & 0.550 \\
\hline $\mathrm{Fe}^{2+}$ & 0.873 & 1.409 & 1.027 & 0.737 & 1.329 & 0.520 \\
\hline $\mathrm{Mn}$ & 0.012 & 0.005 & 0.000 & 0.011 & 0.014 & 0.005 \\
\hline $\mathrm{Mg}$ & 0.095 & 0.088 & 0.002 & 0.110 & 0.151 & 0.184 \\
\hline $\mathrm{Ca}$ & 0.001 & 0.001 & 0.002 & 0.000 & 0.001 & 0.000 \\
\hline Total & 2.000 & 3.000 & 3.000 & 2.000 & 3.000 & 3.000 \\
\hline
\end{tabular}

* Total iron from microprobe analyses

$I l m=$ ilmenite,$M t=$ magnetite, $P s b=$ pseudobrookite

\section{Oxide mineralogy}

Polished thin sections of the natural samples (NS) and experimental run products (RP) were examined optically in transmitted and reflected light. Textures and compositions of the NS and RP were examined with a Hitachi (S-570) scanning electron microscope (SEM) and automated CAMECA electron microprobe (EM) at the University of Michigan. Operating conditions for the microprobe were $15 \mathrm{kV}$ and $10 \mathrm{nA}$. Analyses were obtained using a variety of natural and synthetic standards applying a CAMECA $\mathrm{ZAF}$ correction procedure. The synthetic standards were: $\mathrm{TiO}_{2}, \mathrm{~V}_{2} \mathrm{O}_{5}, \mathrm{MgTiO}_{3}$, and $\mathrm{Fe}_{2} \mathrm{O}_{3}$. The natural standards were: spinel, jacobsite, uvarovite, and wollastonite. Microprobe analyses of heterogeneous phases were obtained by rastering the electron beam over a $15 \mu \mathrm{m}^{2}$ area for $30 \mathrm{~s}$. Reintegration of heterogeneous phases was done in an attempt to obtain the original high temperature $\mathrm{Fe}-\mathrm{Ti}$ oxide compositions as suggested by Buddington and Lindsley (1964). Ferric iron concentrations were calculated based on stoichiometry and charge balance considerations. Unfortunately, low sample availability prevented further ferric/ferrous determinations by application of either Mossbauer (Wood and Virgo 1988) or wet chemical techniques. Representative microprobe analyses of each mineral phase from both the NS and RP are presented in Tables 2, 3, 4.

With hindsight, it is regrettable that the aliquots recovered from the cell-imposed oxidized and reduced runs were
Table 3. Representative microprobe analyses: Middle Zone \#4371

\begin{tabular}{|c|c|c|c|c|c|}
\hline & \multicolumn{2}{|c|}{ Natural sample } & \multicolumn{3}{|c|}{ Run products } \\
\hline & $\mathrm{Ilm}$ & Mt & $\mathrm{Ilm}$ & Mt & Psb \\
\hline \multicolumn{6}{|c|}{ Oxide Wt $\%$} \\
\hline $\mathrm{SiO}_{2}$ & 0.02 & 0.06 & 0.02 & 0.10 & 0.00 \\
\hline $\mathrm{TiO}_{2}$ & 51.96 & 17.57 & 44.50 & 17.97 & 61.07 \\
\hline $\mathrm{Al}_{2} \mathrm{O}_{3}$ & 0.09 & 3.86 & 0.40 & 2.64 & 0.60 \\
\hline $\mathrm{Cr}_{2} \mathrm{O}_{3}$ & 0.00 & 0.09 & 0.04 & 0.06 & 0.02 \\
\hline $\mathrm{V}_{2} \mathrm{O}_{3}$ & 0.43 & 1.96 & 0.64 & 1.23 & 0.50 \\
\hline $\mathrm{Fe}_{2} \mathrm{O}_{3}$ & 2.45 & 27.88 & 13.70 & 28.26 & 14.57 \\
\hline $\mathrm{FeO}$ & 41.75 & 45.45 & 33.99 & 42.62 & 17.74 \\
\hline $\mathrm{MnO}$ & 0.48 & 0.39 & 0.42 & 0.37 & 0.11 \\
\hline $\mathrm{MgO}$ & 2.53 & 1.19 & 3.13 & 2.64 & 3.35 \\
\hline $\mathrm{CaO}$ & 0.00 & 0.02 & 0.03 & 0.03 & 0.02 \\
\hline Total & 99.71 & 98.47 & 96.87 & 95.91 & 97.98 \\
\hline $\mathrm{FeO}^{*}$ & 43.96 & 70.53 & 46.31 & 68.06 & 30.85 \\
\hline \multicolumn{6}{|c|}{ Mole percent } \\
\hline $\mathrm{Si}$ & 0.000 & 0.002 & 0.000 & 0.002 & 0.000 \\
\hline $\mathrm{Ti}$ & 0.971 & 0.492 & 0.855 & 0.514 & 1.768 \\
\hline $\mathrm{Al}$ & 0.003 & 0.169 & 0.012 & 0.118 & 0.027 \\
\hline $\mathrm{Cr}$ & 0.000 & 0.003 & 0.001 & 0.002 & 0.000 \\
\hline $\mathrm{V}^{3+}$ & 0.009 & 0.058 & 0.013 & 0.038 & 0.015 \\
\hline $\mathrm{Fe}^{3+}$ & 0.047 & 0.781 & 0.263 & 0.808 & 0.422 \\
\hline $\mathrm{Fe}^{2+}$ & 0.868 & 1.415 & 0.726 & 1.355 & 0.571 \\
\hline $\mathrm{Mn}$ & 0.008 & 0.012 & 0.010 & 0.012 & 0.004 \\
\hline $\mathrm{Mg}$ & 0.094 & 0.067 & 0.119 & 0.150 & 0.192 \\
\hline $\mathrm{Ca}$ & 0.000 & 0.001 & 0.001 & 0.001 & 0.001 \\
\hline Total & 2.000 & 3.000 & 2.000 & 3.000 & 3.000 \\
\hline
\end{tabular}

* Total iron from microprobe analyses

$I l m=$ ilmenite, $M t=$ magnetite, $P S b=$ pseudobrookite

combined, even though the aliquots showed identical $\mathrm{fO}_{2}-$ $T$ values and the same degree of autoreduction was observed irrespective of cell memory. It appeared that postmortem analysis would not be materially affected by the cell-memory direction from which $\mathrm{fO}_{2}$ equilibrium was achieved. Changes in texture and appearance of different phases in RP compared with the NS suggest that the optimal approach for future studies would be to avoid combining post-run aliquots.

\section{$M Z$ cumulate (4359)}

MZ cumulate (4359) consists of three oxide phases; ilmenite $\left(\mathrm{ilm}_{88} \mathrm{Gk}_{10} \mathrm{Hem}_{02}\right)$, ulvospinel-magnetite $\left(\mathrm{Usp}_{52}-\right.$ $\left.\mathrm{Spin}_{09} \mathrm{Mt}_{39}\right)$ and a magnetite-rich spinel $\left(\mathrm{Usp}_{03} \mathrm{Mt}_{97}\right)$, which appears to have exsolved from the host ulvospinelmagnetite (Fig. 7a). The ulvospinel-magnetite is heterogeneous on the micrometer scale (Vincent and Phillips 1954, Plate 7; Wager and Brown 1967, Fig. 26, p. 51). The magnetite-rich spinel, which represents less than five percent of the total oxide volume, occurs as either exsolved blebs within the ulvospinel-magnetite or thin rims along grain boundaries. In contrast, the grains from the experimental $\mathrm{RP}$ are different in both texture and chemical composition from the NS (Fig. 7b). Ubiquitous fine-grained exsolution textures present in the NS have been destroyed and replaced by grains with an annealed appearance. The most striking difference between the NS and the RP, is the appearance 
Table 4. Representative microprobe analyses: Lower Zone \#5107

\begin{tabular}{|c|c|c|c|c|}
\hline & \multicolumn{2}{|c|}{ Natural sample } & \multicolumn{2}{|c|}{ Run products } \\
\hline & $\mathrm{Ilm}$ & $\mathrm{Mt}$ & $\mathrm{Ilm}$ & Mt \\
\hline \multicolumn{5}{|c|}{ Oxide Wt \% } \\
\hline $\mathrm{SiO}_{2}$ & 0.03 & 0.46 & 0.01 & 0.09 \\
\hline $\mathrm{TiO}_{2}$ & 47.69 & 11.48 & 47.28 & 19.25 \\
\hline $\mathrm{Al}_{2} \mathrm{O}_{3}$ & 0.05 & 2.31 & 0.57 & 4.04 \\
\hline $\mathrm{Cr}_{2} \mathrm{O}_{3}$ & 0.06 & 0.12 & 0.06 & 0.02 \\
\hline $\mathrm{V}_{2} \mathrm{O}_{3}$ & 0.67 & 1.31 & 0.51 & 0.61 \\
\hline $\mathrm{Fe}_{2} \mathrm{O}_{3}$ & 10.01 & 40.04 & 11.83 & 27.26 \\
\hline $\mathrm{FeO}$ & 37.29 & 40.48 & 33.95 & 43.32 \\
\hline $\mathrm{MnO}$ & 0.33 & 0.23 & 0.33 & 0.31 \\
\hline $\mathrm{MgO}$ & 2.94 & 0.72 & 4.58 & 3.69 \\
\hline $\mathrm{CaO}$ & 0.04 & 0.05 & 0.06 & 0.02 \\
\hline Total & 99.11 & 97.20 & 99.18 & 98.61 \\
\hline $\mathrm{FeO}^{*}$ & 46.30 & 76.51 & 44.60 & 67.85 \\
\hline \multicolumn{5}{|c|}{ Mole percent } \\
\hline $\mathrm{Si}$ & 0.001 & 0.018 & 0.001 & 0.003 \\
\hline $\mathrm{Ti}$ & 0.897 & 0.331 & 0.876 & 0.527 \\
\hline $\mathrm{Al}$ & 0.002 & 0.104 & 0.016 & 0.174 \\
\hline $\mathrm{Cr}$ & 0.001 & 0.004 & 0.001 & 0.000 \\
\hline$V^{3+}$ & 0.013 & 0.040 & 0.010 & 0.018 \\
\hline $\mathrm{Fe}^{3+}$ & 0.188 & 1.155 & 0.219 & 0.747 \\
\hline $\mathrm{Fe}^{2+}$ & 0.780 & 1.298 & 0.700 & 1.320 \\
\hline $\mathrm{Mn}$ & 0.007 & 0.007 & 0.007 & 0.010 \\
\hline $\mathrm{Mg}$ & 0.110 & 0.041 & 0.168 & 0.200 \\
\hline $\mathrm{Ca}$ & 0.001 & 0.002 & 0.002 & 0.001 \\
\hline Total & 2.000 & 3.000 & 2.000 & 3.000 \\
\hline
\end{tabular}

* Total iron from microprobe analyses

$I l m=$ ilmenite, $M t=$ magnetite

of ferropseudobrookite $\left(\mathrm{Fpb}_{53} \mathrm{Kar}_{19} \mathrm{Psb}_{28}\right)$ blebs in the cores of some RP ilmenite grains. The ferropseudobrookite is always found in the host ilmenite and never appears in contact with magnetite. The RP ilmenite ( $\operatorname{Ilm}_{75} \mathrm{Gk}_{11}$ $\left.\mathrm{Hem}_{14}\right)$, and magnetite $\left(\mathrm{Usp}_{40} \mathrm{Sp}_{15} \mathrm{Mt}_{45}\right)$ have a higher ferric iron component than the respective NS phases.
Volume estimates were made using an image analyzer AppleII attached to the SEM. Complex exsolution textures and subtle contrast between phases generated large errors $(>10 \%)$ in estimating volumes of the phases present. Although volume estimates are rough at best, ferropseudobrookite represents approximately thirty percent of the RP in MZ cumulate (4359).

\section{$M Z(4371)$}

The magnetic fraction of NS (4371) consists of ilmenite $\left(\mathrm{Ilm}_{88} \mathrm{Gk}_{10} \mathrm{Hem}_{02}\right.$ ) and heterogeneous ulvospinel-magnetite $\left(\mathrm{Usp}_{52} \mathrm{Sp}_{07} \mathrm{Mt}_{41}\right.$ ) (Fig. 8a). The RP are chemically and texturally different from the NS. Again, the original exsolution textures have been annealed and ferropseudobrookite $\left(\mathrm{Fpb}_{58} \mathrm{Kar}_{20} \mathrm{Psb}_{22}\right)$ has formed in the cores of some ilmenite grains (Fig. 8 b). The volume of ferropseudobrookite is significantly less than in the MZ cumulate (4359) totalling about two percent by volume. The composition of the RP ilmenite $\left(\mathrm{Ilm}_{75} \mathrm{Gk}_{12} \mathrm{Hem}_{13}\right)$ and magnetite $\left(\mathrm{Usp}_{53} \mathrm{Sp}_{06} \mathrm{Mt}_{41}\right)$ appear to have a higher ferric iron component than the respective NS phases.

\section{$L Z(5107)$}

The concentrated magnetic fraction from natural sample LZ (5107) consists mainly of ilmenite ( $\operatorname{Ilm}_{79} \mathrm{Gk}_{11} \mathrm{Hem}_{10}$ ) and magnetite $\left(\mathrm{Usp}_{35} \mathrm{Sp}_{05} \mathrm{Mt}_{60}\right)$ with minor olivine, plagioclase, and pyroxene (Fig. 9a). In contrast to the Middle Zone RP samples, there is no ferropseudobrookite in the RP of the Lower Zone sample (Fig. 9b). Exsolution textures in most of the RP ilmenite ( $\mathrm{Ilm}_{72} \mathrm{Gk}_{17} \mathrm{Hem}_{11}$ ) and magnetite $\left(\mathrm{Usp}_{50} \mathrm{Sp}_{09} \mathrm{Mt}_{41}\right)$ grains have been annealed.

\section{Discussion of Probe and SEM Data}

The unexpected appearance of ferropseudobrookite in the RP of the MZ samples either represents a change in the bulk chemistry of the system, or localized changes in the chemical composition of individual phases with no net change in bulk composition. Magnetite and ferropseudobrookite are incompatible (Lindsley 1976), whereas ilmen-

\section{Middle Zone \# 4359}

Natural Sample

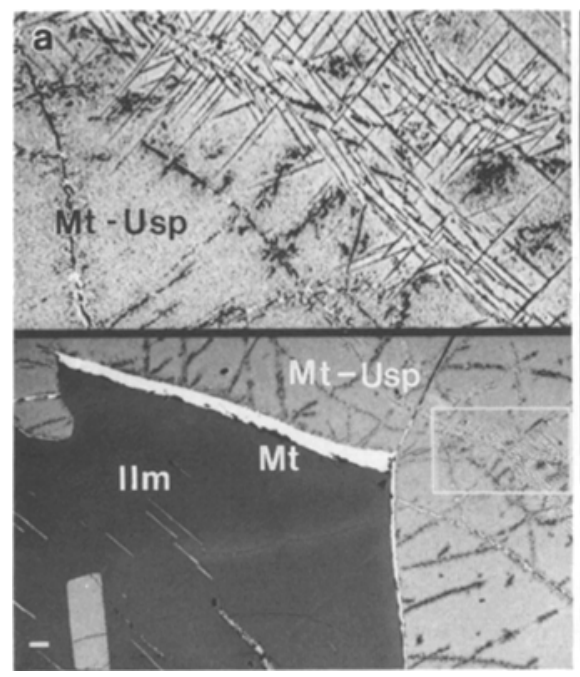

Run Products

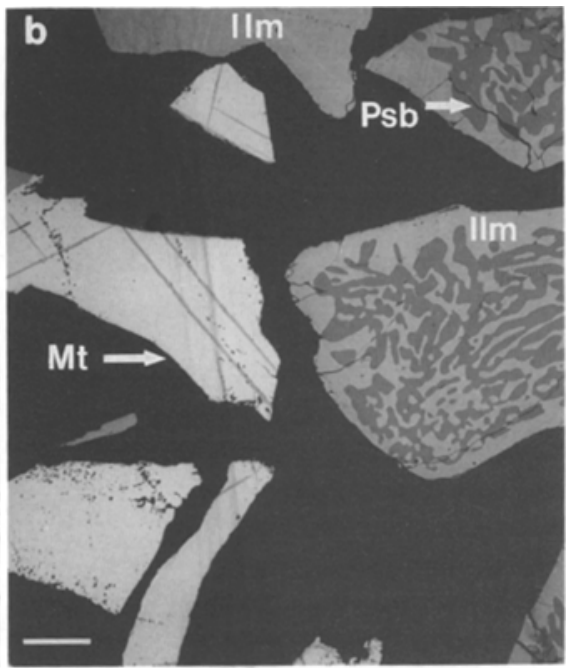

Fig. 7a, b. SEM photos of the NS and RP of Middle Zone cumulate (4359). a A split image of the NS taken at $100 \times$ magnification and $15 \mathrm{kV}$. Scale bar located in the lower left of the photo is $50 \mu \mathrm{m}$. The bottom half of the photo shows an ilmenite grain (right), a thin rim of magnetite-rich spinel (center), and a heterogeneous magnetite-ulvospinel intergrowth (left). The top of the photo shows the boxed magnetite-ulvospinel intergrowth magnified an additional five times. b The photo shows the three phases in the RP: ilmenite, magnetite, and ferropseudobrookite taken at $200 \times$ magnification and $15 \mathrm{kV}$. The scale bar in the bottom left is $50 \mu \mathrm{m}$. The ferropseudobrookite is the dark symplectite that occurs inside the host ilmenite. Ilmenite exsolution is sometimes present in the magnetite host. Note the different textural appearance between the NS and RP 

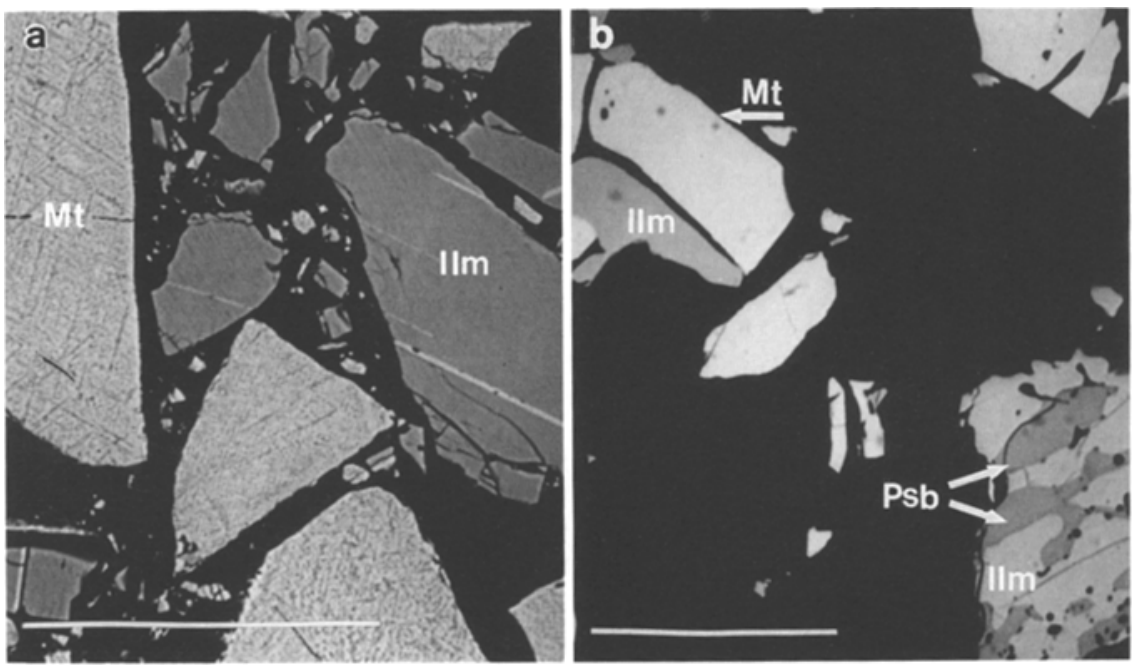

Fig. 8a, b. SEM photos of the NS and RP of Middle Zone (4371). a The two phases are a heterogeneous magnetite-ulvospinel similar to Fig. $7 \mathrm{a}$, and an ilmenite taken at $700 \times$ magnification and $15 \mathrm{kV}$. The scale bar in the lower left is $50 \mu \mathrm{m}$. b The RP photo shows ferropseudobrookite hosted in an ilmenite grain. In this sample, ferropseudobrookite is much rarer than the RP sample (4359). This photo was taken at $690 \times$ magnification and $15 \mathrm{kV}$. The scale bar in the lower left is $50 \mu \mathrm{m}$

Lower Zone \# 5107

\section{Natural Sample}

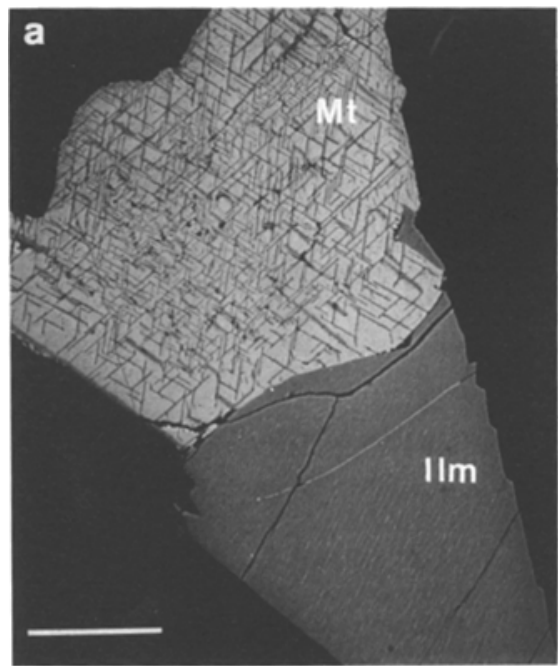

\section{Run Products}

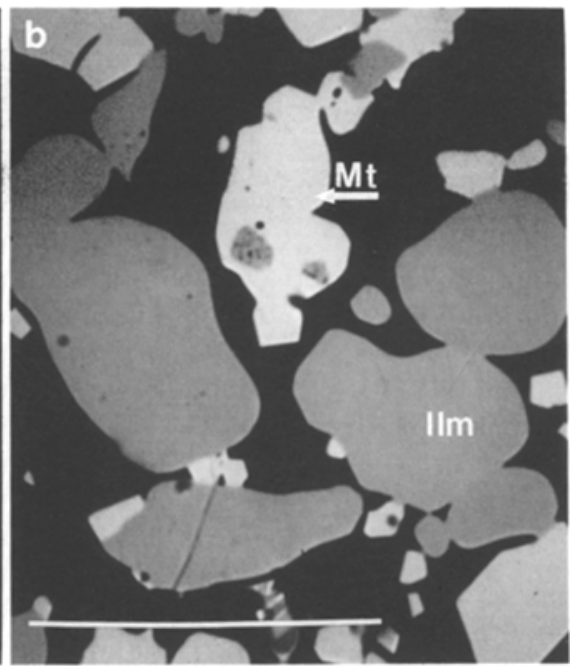

Fig. 9a, b. SEM photos of the NS and RP of Lower Zone (5107). a An ilmenite (bottom right) and a magnetite (top left) grain at $400 \times$ magnification and $20 \mathrm{kV}$ are shown. Scale bar in the bottom left is $50 \mu \mathrm{m}$. The ilmenite grain has fine magnetite exsolution and the magnetite shows ilmenite exsolution in four well developed directions. b Ilmenite and magnetite grains at $1000 \times$ magnification and $15 \mathrm{kV}$. The scale bar in the lower left is $50 \mu \mathrm{m}$. The two photos demonstrate the change in textural appearance in the phases before and after the experiment. Ubiquitious exsolution in the NS magnetite and ilmenite is almost entirely absent in the RP ite-ferropseudobrookite and ilmenite-magnetite assemblages are stable albeit with slight differences in ilmenite compositions. Microprobe analyses (Tables 2, 3, 4) for representative NS and RP have been projected onto $\mathrm{FeO}-$ $\mathrm{Fe}_{2} \mathrm{O}_{3}-\mathrm{TiO}_{2}$ ternary diagrams (Fig. 10). Non-ternary components were subtracted from the analyses using the recalculation scheme of Stormer (1983) before projection. Tie-lines connect the coexisting equilibrium phases in each sample. Interpretation of the $\mathrm{FeO}-\mathrm{Fe}_{2} \mathrm{O}_{3}-\mathrm{TiO}_{2}$ ternary projection for the MZ samples is ambiguous in determining whether or not the bulk composition has been experimentally altered, although changes in the individual mineralogy of the phases has occurred. Unfortunately, the errors inherent in calculating bulk compositions using image analysis techniques were too large to determine if the total composition of the system had changed during the experiments.

A companion study of a magnesian ilmenite megacryst from Monastery Kimberlite pipe, South Africa, in which aliquot separation was maintained showed identical phase relationships (irrespective of imposed cell-memory), and a number of chemical similarities with the RP of the MZ Skaergaard samples (Loureiro et al. 1989). We emphasize that SEM/EM analysis of RP should be an essential component of electrochemical studies of $\mathrm{fO}_{2}-T$ equilibria, and that detailed understanding of the nature of these equilibria can only be attained with this type of approach.

The sequence of measurements employed by Loureiro et al. (1988) to measure the $\mathrm{fO}_{2}$ of a Monastery ilmenite $\left(\mathrm{Ilm}_{56} \mathrm{Gk}_{31} \mathrm{Hem}_{13}\right)$ was identical to those used in this study. The measured 1 bar equilibrium for both the oxidized and reduced runs for Mon-264-il-41 is $\log f \mathrm{O}_{2}=(-19992 / T)+$ $6.38(r=0.9982)$, which plots near the nickel-nickel oxide (NNO) buffer. Virgo et al. (1988) obtained similar values at high temperature on the same ilmenite. Although this sample was initially thought to be a single phase ilmenite, SEM and EM examination shows that the NS consists of ilmenite together with minor sphene and perovskite. The experimental RP (separately preserved as oxidized and re- 


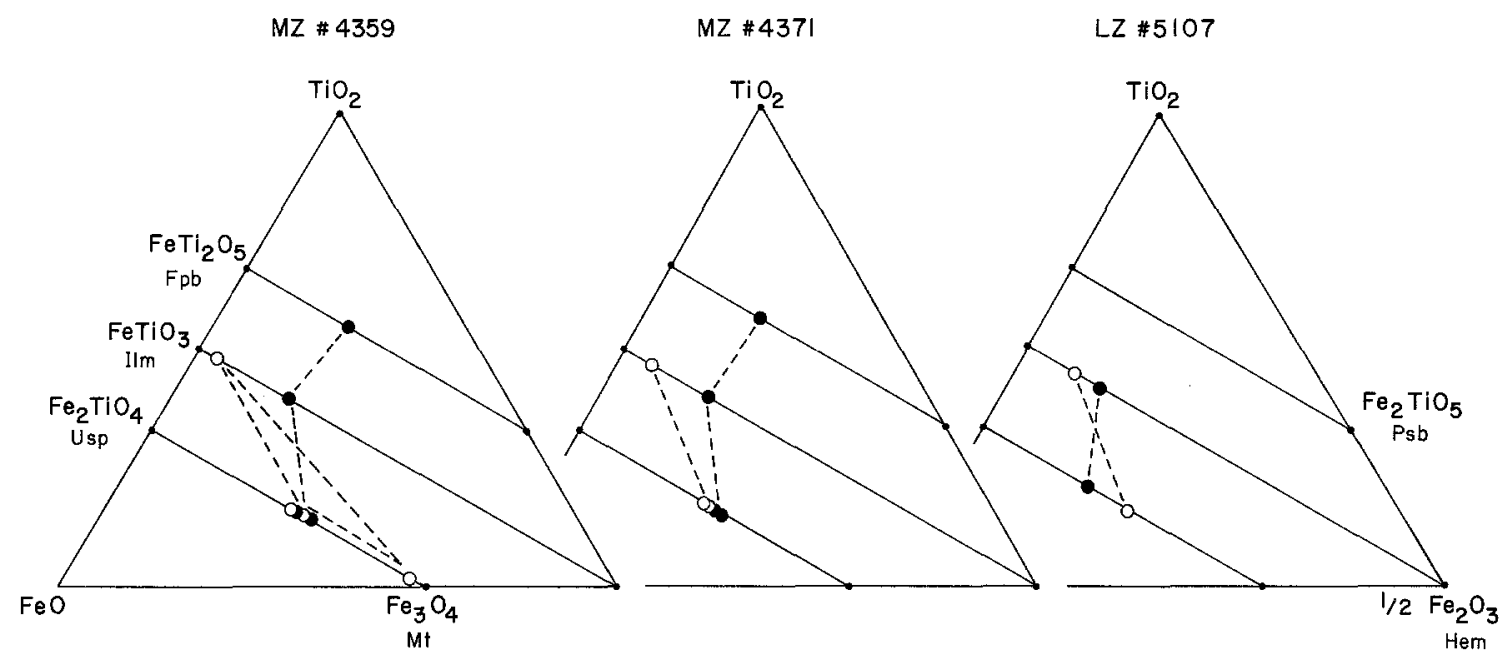

Fig. 10. $\mathrm{FeO}-\mathrm{Fe}_{2} \mathrm{O}_{3}-\mathrm{TiO}_{2}$ mole percent projection of both the NS and RP of the three Skaergaard samples. Non-ternary cations were eliminated using the calculation of Stormer (1983). Pseudobrookite was calculated by subtracting out excess $\mathrm{MgTi}_{2} \mathrm{O}_{5}$ and (cations $\left.{ }^{3+}\right)_{2} \mathrm{TiO}_{5}$ and then normalizing the remaining $\mathrm{Fe}^{2+}-\mathrm{Fe}^{3+}-\mathrm{Ti}$. Tie lines connect equilibrium coexisting phases. $0 \mathrm{NS}$, $\bullet \mathrm{RP}$. $F p b$ ferropseudobrookite, $P s b$ pseudobrookite, $I m$ ilmenite, Hem hematite, Usp ulvospinel, $M t$ magnetite

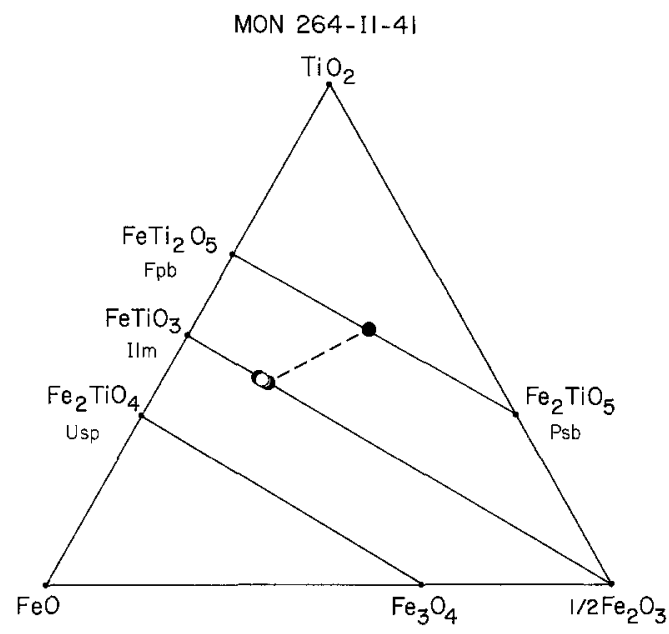

Fig. 11. $\mathrm{FeO}-\mathrm{Fe}_{2} \mathrm{O}_{3}-\mathrm{TiO}_{2}$ mole percent projection of both the NS and RP from Monastery 264-il-41. Although the projected NS composition has oxidized to ilmenite + pseudobrookite during the course of the experiment, the ilmenite RP remains similar to the original NS composition. o NS, • RP

duced aliquots) are ilmenite $\left(\operatorname{Ilm}_{57} \mathrm{Gk}_{30} \mathrm{Hem}_{13}\right)$ and ferropseudobrookite $\left(\mathrm{Fpsb}_{32} \mathrm{Kar}_{40} \mathrm{Psb}_{28}\right)$. Although ferropseudobrookite is more abundant in the RP from the oxidized direction, several grains were also observed in the RP from the reduced direction indicating that the occurrence of ferropseudobrookite is largely independent of cell memory. These results are plotted on a $\mathrm{FeO}-\mathrm{Fe}_{2} \mathrm{O}_{3}-\mathrm{TiO}_{2}$ ternary diagram in Fig. 11 and suggest that the bulk composition of the sample has changed in an oxidized direction during the experimental study.

McMahon (1984) has independently determined the $f \mathrm{O}_{2}-T$ single-phase stability field for a similar Monastery ilmenite ( $\left(\mathrm{Ilm}_{54} \mathrm{Gk}_{33} \mathrm{Hem}_{13}\right)$ by quenching experiments. The experimental curve corresponds closely to the NNO buffer at 1 bar $\left(\log f \mathrm{O}_{2}=(-9337 / T)-2.13\right.$ with $T$ in Kelvin $)$. The upper oxidized limit to the single phase field results in the appearance of pseudobrookite, whereas the reduced limit is characterized by the appearance of a magnesian-titano- magnetite. The remarkably close correspondence between these two independent methods (Loureiro et al. 1989; McMahon 1984) for determination of the redox state for similar Monastery ilmenite megacrysts is encouraging. Furthermore, these data suggest that the appearance of ferropseudobrookite in the electrochemical cell determinations can represent a surprisingly insignificant change in the phase composition, and that the natural ilmenite is in fact very close to ferropseudobrookite saturation.

Although the appearance of ferropseudobrookite in the RP of the MZ Skaergaard samples and the Monastery ilmenite could be attributed to oxidation during the electrochemical cell experiments, it is not obvious what the source of this oxidation might be, given the appearance of this phase in RP subjected to an imposed "reduced" cell memory. Furthermore, no ferropseudobrookite has been detected in the RP of the Skaergaard LZ (5107), although this sample was subjected to the same experimental procedure as the MZ samples. The RP magnetite and ilmenite phases of LZ (5107) do not show large apparent compositional changes in the oxidized direction compared with the NS, further suggesting that the LZ sample was not oxidized during the experiment.

If the Fe-saturated platinum capsules absorbed additional $\mathrm{Fe}$ from the sample during the experiment, oxygen would be released into the sample capsule irrespective of the initial cell memory. It is possible that minor oxygen has been introduced causing localized oxidation of ilmenite to ferropseudobrookite in those samples (Monastery and Skaergaard MZ) close to ferropseudobrookite saturation, while leaving samples further from ferropseudobrookite saturation undetectably altered (Skaergaard LZ).

Delano (personal comm.) has recently shown that electrochemical experiments using samples placed in either $\mathrm{Fe}$ saturated platinum capsules or high purity alumina ceramics yield identical results. It would appear that the use of the platinum capsules had not contributed to the alteration of the sample.

Ferropseudobrookite is never in contact with the magnetite of the Skaergaard samples (Figs. $7 \mathrm{~b}$ and $8 \mathrm{~b}$ ), which suggests that although local disequilibrium has occurred 
through the oxidation of ilmenite to ferropseudobrookite, the original magnetite-ilmenite redox condition remains unaffected by the presence of ferropseudobrookite. It is possible that longer experimental runs would produce more ferropseudobrookite at the expense of magnetite creating an ilmenite-ferropseudobrookite buffer which might eventually dominate the $f \mathrm{O}_{2}$ of the system. This is unlikely because the experimental run time for MZ (4371), which has much less ferropseudobrookite, took ten to twenty hours longer to run than MZ cumulate (4359). Alternatively, rapid (unreversed) and localized oxidation of the ilmenite during initial run up to temperature could be involved. Further experiments would be required as no direct correlation with run time can be made based on the present set of experiments alone. The run time for one aliquot of sample (test 2 or 4) ranged from $27 \mathrm{~h}$ to $72 \mathrm{~h}$ depending on the sample behavior.

\section{Magnetite-ilmenite thermometry}

The Fe-Ti oxide thermometer/oxygen barometer of Buddington and Lindsley (1964) (BL), Spencer and Lindsley (1981) (SL), and Anderson and Lindsley (1988) (AL) were applied to the same microprobe analyses of coexisting magnetite and ilmenite pairs in an effort to compare experimentally determined with calculated $f \mathrm{O}_{2}$ 's.

In order to calculate the chemical formulae for the coexisting iron-titanium oxides in $\mathrm{Fe}-\mathrm{Ti}-\mathrm{O}$ space, a recalculation scheme that corrects for minor cation constituents must be used. Ignoring minor constituents may yield large errors in both temperature and $\mathrm{fO}_{2}$ (Stormer 1983). Many approaches have been proposed (Buddington and Lindsley 1964; Carmichael 1967; Anderson 1968; Ghiorso and Carmichael 1981; Spencer and Lindsley 1981; Lindsley and Spencer 1982; Stormer 1983; Anderson and Lindsley 1988), all of which make different assumptions in dealing with non-ternary cations, yielding substantial variation in calculated components. The recalculation scheme chosen for elimination of additional components was that of Stormer (1983). These Skaergaard samples contain relatively pure magnetite and ilmenite pairs where non-ternary cations do not exceed ten mole percent of the total, significantly reducing the error in the calculated $f \mathrm{O}_{2}-T$ determinations. Ferric iron was calculated on the basis of charge balance and stoichiometry using total $\mathrm{FeO}$ from microprobe analyses.

Recalculation models introduce a systematic bias in the data set making direct comparison between different schemes difficult. Reliance on incomplete thermodynamic data sets, and biases in recalculation models for non-ternary cation components are inherent assumptions necessary for calculating temperature and $f \mathrm{O}_{2}$ 's with unknown potential inaccuracies in the calculated result. Although progress in our understanding of complex exchange equilibria has been achieved, thermodynamic models and present recalculation schemes are far from perfect. The distinct potential advantage of direct emf measurements is the elimination of most of these assumptions and the provision of a powerful alternative to thermodynamic calculations.

\section{Discussion of thermometry}

Regardless of the thermometer used, (BL, SL, or AL) all estimated $f \mathrm{O}_{2}-T$ values for the Skaergaard RP plot above
FMQ and are in good agreement with the experimentally measured values (Figs. 4-6). The calculated temperatures and $\mathrm{fO}_{2}$ 's plot near the purge temperature value, which is the last temperature the sample reached before being removed from the furnace. The square symbols in Figs. 4 6 , represent purge temperatures. Error bars are drawn for the BL thermometer. The three different thermometers cluster in $f \mathrm{O}_{2}-T$ space spanning less than $1 \log$ unit and $50^{\circ}$.

In order to calculate $f \mathrm{O}_{2}-T$ for the NS, extrapolations near the limits of the graphical data base of BL (1964) and AL (1988) must be used. Problematical calculations using reintegrated $\mathrm{Fe}-\mathrm{Ti}$ oxide analyses reveal unrealistically low temperatures ranging between $300^{\circ}-800^{\circ} \mathrm{C}$, suggestive of reset subsolidus temperatures.

Other investigators have successfully calculated $f \mathrm{O}_{2}-T$ of reintegrated coexisting ilmenite-magnetite pairs from the Layered Series (Buddington and Lindsley 1964; Morse et al. 1980). For the same stratigraphic units of the Middle and Lower Zones, both Buddington and Lindsley (1964) and Morse et al. (1980) independently calculated similar $f \mathrm{O}_{2}-T$ values near FMQ. Table 1 compares the calculated $\mathrm{fO}_{2}-T$ of the RP of this study using the Buddington and Lindsley thermometer, and estimated $f \mathrm{O}_{2}-T$ from other investigators for the Layered Series. All these calculated values are within $1.0 \mathrm{log}$ unit of the experimentally measured values from this paper.

\section{Ilmenite-ferropseudobrookite thermometry}

To compare the ilmenite-magnetite and ilmenite-pseudobrookite redox equilibria for the two Middle Zone RP phase assemblages, ilmenite-pseudobrookite oxygen barometry was applied using the theoretical model of Anovitz et al. (1985). Due to the large temperature variations with small changes in composition that result from oblique intersections of the isopleths, this calibration yields large variations in temperature estimates and is most useful as an oxygen barometer (Anovitz et al. 1985). The results calculated with this thermometer (Figs. 4 and 5) are slightly more oxidized than the experimental data but vary widely in temperature, up to $300^{\circ}$ for one sample. The $f \mathrm{O}_{2}$ estimates most consistent with the experimental values have been plotted in Figs. 4 and 5. Using the best fit temperature values, the MZ cumulate (4359) plots 0.2 of a log unit and $M Z$ (4371) plots $1 \log$ unit above the experimental curve respectively, although differences in temperature could significantly change this projection resulting in a different $f \mathrm{O}_{2}-T$ pair.

The relatively good agreement between the experimental results obtained in this study and $f \mathrm{O}_{2}-T$ estimates from both the ilmenite-magnetite and ilmenite-ferropseudobrookite thermometers may indicate that the Skaergaard $\mathrm{MZ}$ samples are close to ferropseudobrookite saturation. It is unlikely that calculated $f \mathrm{O}_{2}-T$ equilibria from coexisting ilmenite-magnetite pairs would produce values close to the experimentally determined curve if the ilmenite-ferropseudobrookite redox were the controlling buffer assemblage. Instead, the chemically altered Middle Zone RP assemblage (in an apparent oxidized direction) does not appear to have significantly altered the $f \mathrm{O}_{2}-T$ equilibria recorded by the original ilmenite-magnetite pairs of the $\mathrm{MZ}$ samples. 


\section{Discussion}

The influence of pressure on experimental oxygen fugacity determinations has been ignored up to this point in the present discussion. Inasmuch as the Skaergaard is considered to have been emplaced at shallow depth (1.2 kbar at the base of the LZ) (McBirney 1975), the pressure effect results in only a small correction in the 1-bar $\mathrm{fO}_{2}$ measurements.

The composition of the sample should not be altered during the experiment. This investigation has shown that the $\mathrm{MZ}$ samples have been oxidized as evidenced by the appearance of ferropseudobrookite in the run products. Although in the worst possible case, the experimentally determined oxygen fugacities approximately $1 \mathrm{log}$ unit above FMQ for the Skaergaard Middle Zone represent a maximum $f \mathrm{O}_{2}$, in part controlled by the appearance of ferropseudobrookite, agreement of experimental data with calculated $\mathrm{fO}_{2}$ values from $\mathrm{Fe}-\mathrm{Ti}$ oxide pairs indicate that the measured oxygen fugacity is a reflection of the original buffered assemblage. If the $f \mathrm{O}_{2}-T$ equilibria measured by electrochemical cells result solely from the experimentally-induced oxidized mineral assemblage, and were not reflective of the original Skaegaard samples, agreement between the $\mathrm{fO}_{2}-T$ of the coexisting ilmenite-magnetite RP pairs and the experimental data would not be expected.

The lack of ferropseudobrookite in the LZ sample coupled with the similar $f \mathrm{O}_{2}-T$ values for all three Skaergaard samples indicates that the $\mathrm{fO}_{2}$ of these Skaergaard samples is indeed closely represented by the experimental values that lie 1.5-0.5 log unit above FMQ.

As emphasized earlier, different approaches to $f \mathrm{O}_{2}-T$ determinations, whether they are experimental or calculated should yield consistent results, or the differences understood. This emf study together with thermodynamic calculations applied to the same well buffered assemblages, yields concordant results within the error bars of the calculations. In addition, previous $f \mathrm{O}_{2}-T$ equilibria studies of Buddington and Lindsley (1964) and Morse et al. (1980) on different rocks within the same Skaergaard units result in $\mathrm{fO}_{2}-T$ determinations within 0.5 of a $\log$ unit of those presented in this paper (Table 1). In contrast, these results do not agree with previous electrochemically-determined $\mathrm{fO}_{2}$ 's from oxide separates of the same Skaergaard units (Sato and Valenza 1980). We do not have an explanation for this discrepancy, although different levels of indigenous carbon in the investigated materials is a possible factor. Further study of exchanged materials might help to resolve the issue.

The measured $f \mathrm{O}_{2}$ 's slightly above FMQ suggest that the Skaergaard either equilibrated under relatively oxidized conditions, or that the primary igneous signature has been disrupted by subsolidus reequilibration. Although the results from this study cannot distinguish between these two possibilities, other studies suggest that the Skaergaard has undergone subsolidus alteration. The oxygen isotopic studies of Taylor and Forester (1979) and Norton and Taylor (1979) indicate that the Skaergaard has undergone a major hydrothermal event. Surrounding rocks in the vicinity of the Skaergaard have isotopic signatures indicative of meteoric-hydrothermal exchange (Taylor and Forester 1979). The $\delta^{18} \mathrm{O}$ contours cut across primary stratigraphic units, which indicate that most of the $\delta^{18} \mathrm{O}$ variation is the result of secondary sub-solidus exchange. Middle and Lower Zone plagioclase $\delta^{18} \mathrm{O}$ values range between 5.7 (characteristic of unaltered basalt) and more depleted values near 2.5 (Taylor and Forester 1979). In spite of the complicated subsolidus ${ }^{18} \mathrm{O}$ exchange reactions that have occurred in the Skaergaard, it is not clear how this behavior has affected the $\mathrm{Fe}^{3+} / \mathrm{Fe}^{2+}$ ratio of the coexisting $\mathrm{Fe}-\mathrm{Ti}$ oxides. If this ratio has changed subsequent to solidification of the magma, then the measured $f \mathrm{O}_{2}-T$ values are not reflective of primary magmatic conditions.

\section{Conclusion}

These experiments demonstrate the potential precision, accuracy and high resolution of the solid electrolyte method as applied to natural samples. Experimental runs on each sample, from the reduced direction and the oxidized direction provide reversals which agree to better than 0.2 of a $\log$ unit. These tight reversals reveal the reproducibility of the experimental data and show that the measured redox state of the sample is apparently independent of the initial cell-imposed conditions.

Future electrochemical cell investigations of natural rock and mineral samples should include careful characterization of the starting materials and run products. Unexpected phase changes of the MZ samples have appeared in the course of experimental study. Only when these changes are characterized and carefully evaluated can informed conclusions be drawn with respect to the validity of the experimental data.

Calculated temperature and $\mathrm{fO}_{2}$ 's from the RP using coexisting $\mathrm{Fe}-\mathrm{Ti}$ oxide pairs are in good agreement with the experimental data. These results also agree with calculated $\mathrm{fO}_{2}$ 's of Buddington and Lindsley (1964) and Morse et al. (1980).

The experiments can help to resolve small differences in $\mathrm{fO}_{2}$ of less than 0.2 of a $\log$ unit. These results indicate that precise measurements can be made using electrochemical cells. The solid electrolyte approach to geologic materials represents a potentially powerful method for the measurement of $\mathrm{O}_{2}$ and other high temperature thermodynamic parameters.

Acknowledgments. Research was supported in part by NSF grant EAR-8417131 to R.J. Arculus, GSA grant 3600-86, a Sigma Xi grant-in-aid of research, and a University of Michigan Turner grant to A.B. Kersting. We appreciate the donation of the Skaergaard samples by Professor G.M. Brown and the assistance of Dr. C.H. Emeleus in their transfer from Durham to Michigan. All experiments were performed in J.W. Delano's laboratory at the State University of New York, Albany. The University of Michigan electron microprobe was obtained with NSF grant EAR-82-12764 and the University of Michigan scanning electron microscope was obm tained through NSF grant BSR 83-14092. C.H. Henderson's expertise helped improve the quality of the quantitative microprobe data. E.J. Essene provided constructive criticism of an early version of the manuscript, and together with R.D. Holmes was a source of much useful comment on the experimental procedures and data obtained. Thanks to S. Fast for her help in drafting the figures. We also thank B.J. Wood and G.C. Ulmer for perceptive reviews. 
Appendix A

Experimental run data

\begin{tabular}{|c|c|c|c|c|c|c|c|c|}
\hline \multirow[b]{2}{*}{ Number } & \multicolumn{4}{|c|}{ Reduced direction } & \multicolumn{4}{|c|}{ Oxidized direction } \\
\hline & Temp $(K)$ & $1 / \mathrm{K} * 10^{4}$ & $\log f \mathrm{O}_{2}$ & Time (min) & Temp $(\mathrm{K})$ & $1 / \mathrm{K}^{*} 10^{4}$ & $\log f \mathrm{O}_{2}$ & Time $(\min )$ \\
\hline \multicolumn{9}{|c|}{ Middle zone cumulate (4359) } \\
\hline 1 & 1060.0 & 9.43 & -12.98 & 60 & 1143.2 & 8.75 & -11.21 & 105 \\
\hline 2 & 1122.0 & 8.91 & -11.71 & 83 & 1208.2 & 8.28 & -10.04 & 100 \\
\hline 3 & 1173.5 & 8.52 & -10.76 & 65 & 1280.1 & 7.81 & -9.04 & 110 \\
\hline 4 & 1230.9 & 8.12 & -9.83 & 65 & 1346.6 & 7.43 & -8.24 & 0 \\
\hline 5 & 1285.4 & 7.78 & -9.09 & 70 & 1346.6 & 7.43 & -8.54 & 200 \\
\hline 6 & 1338.3 & 7.47 & -8.42 & 0 & 1420.0 & 7.04 & -7.81 & 197 \\
\hline 7 & 1338.3 & 7.47 & -8.66 & 270 & 1367.8 & 7.31 & -8.33 & 143 \\
\hline 8 & 1389.0 & 7.20 & -8.14 & 140 & 1295.2 & 7.72 & -9.14 & 78 \\
\hline 9 & 1424.5 & 7.02 & -7.79 & 74 & 1226.4 & 8.15 & -10.09 & 50 \\
\hline 10 & 1403.3 & 7.13 & -7.97 & 72 & 1181.0 & 8.47 & -10.80 & 58 \\
\hline 11 & 1361.7 & 7.34 & -8.38 & 81 & 1311.1 & 7.63 & -8.97 & 70 \\
\hline 12 & 1310.3 & 7.63 & -8.96 & 70 & & & & \\
\hline 13 & 1258.1 & 7.95 & -9.66 & 115 & & & & \\
\hline 14 & 1202.2 & 8.32 & -10.51 & 175 & & & & \\
\hline 15 & 1143.4 & 8.75 & -11.50 & 115 & & & & \\
\hline 16 & 1109.2 & 9.02 & -12.14 & 160 & & & & \\
\hline 17 & 1301.2 & 7.69 & -9.12 & 107 & & & & \\
\hline Purge & 1258.1 & 7.95 & -9.69 & 115 & & & & \\
\hline \multicolumn{9}{|c|}{ Middle zone (4371) } \\
\hline 1 & 1174.9 & 8.51 & -11.51 & 0 & 1219.6 & 8.20 & -10.42 & 160 \\
\hline 2 & 1174.9 & 8.51 & -11.44 & 255 & 1192.3 & 8.39 & -10.92 & 77 \\
\hline 3 & 1205.2 & 8.30 & -10.82 & 90 & 1243.0 & 8.05 & -10.00 & 97 \\
\hline 4 & 1259.6 & 7.94 & -9.89 & 120 & 1291.4 & 7.74 & -9.25 & 90 \\
\hline 5 & 1286.1 & 7.76 & -9.47 & 110 & 1317.1 & 7.59 & -8.92 & 93 \\
\hline 6 & 1314.1 & 7.61 & -9.13 & 173 & 1344.3 & 7.44 & -8.58 & 0 \\
\hline 7 & 1339.8 & 7.46 & -8.79 & 0 & 1344.3 & 7.44 & -8.73 & 710 \\
\hline 8 & 1339.8 & 7.46 & -8.87 & 613 & 1384.4 & 7.22 & -8.25 & 70 \\
\hline 9 & 1385.9 & 7.22 & -8.31 & 61 & 1424.5 & 7.02 & -7.77 & 64 \\
\hline 10 & 1421.5 & 7.03 & -7.87 & 65 & 1404.8 & 7.12 & -7.99 & 48 \\
\hline 11 & 1400.3 & 7.14 & -8.11 & 75 & 1363.2 & 7.34 & -8.51 & 55 \\
\hline 12 & 1368.5 & 7.31 & -8.50 & 80 & 1311.8 & 7.62 & -9.24 & 64 \\
\hline 13 & 1350.4 & 7.41 & -8.75 & 62 & 1268.7 & 7.88 & -9.97 & 90 \\
\hline 14 & 1329.2 & 7.52 & -9.08 & 123 & 1270.2 & 7.87 & -9.87 & 125 \\
\hline 15 & 1297.5 & 7.71 & -9.58 & 110 & 1226.4 & 8.15 & -10.51 & 55 \\
\hline 16 & 1238.5 & 8.07 & -10.58 & 120 & 1334.5 & 7.49 & -8.96 & 137 \\
\hline 17 & 1192.3 & 8.39 & -11.32 & 145 & & & & \\
\hline 18 & 1271.7 & 7.86 & -10.01 & 56 & & & & \\
\hline Purge & & & & & 1311.8 & 7.62 & -9.17 & 48 \\
\hline \multicolumn{9}{|c|}{ Lower zone (5107) } \\
\hline 1 & 1182.5 & 8.46 & -11.79 & 180 & 1121.2 & 8.92 & -12.83 & 0 \\
\hline 2 & 1239.2 & 8.07 & -10.69 & 280 & 1121.2 & 8.92 & -12.70 & 120 \\
\hline 3 & 1238.5 & 8.07 & -10.61 & 400 & 1190.8 & 8.40 & -11.43 & 0 \\
\hline 4 & 1281.5 & 7.80 & -9.98 & 300 & 1190.8 & 8.40 & -11.30 & 120 \\
\hline 5 & 1308.0 & 7.65 & -9.63 & 380 & 1258.1 & 7.95 & -10.21 & 0 \\
\hline 6 & 1345.9 & 7.43 & -9.14 & 275 & 1258.1 & 7.95 & -10.11 & 303 \\
\hline 7 & 1384.4 & 7.22 & -8.62 & 450 & 1313.3 & 7.61 & -9.38 & 90 \\
\hline 8 & 1425.3 & 7.02 & -8.04 & 74 & 1374.6 & 7.27 & -8.64 & 306 \\
\hline 9 & 1405.6 & 7.11 & -8.30 & 203 & 1395.8 & 7.16 & -8.37 & 78 \\
\hline 10 & 1379.1 & 7.25 & -8.65 & 80 & 1426.0 & 7.01 & -7.95 & 65 \\
\hline 11 & 1360.2 & 7.35 & -8.88 & 95 & 1405.6 & 7.11 & -8.22 & 80 \\
\hline 12 & 1339.0 & 7.47 & -9.18 & 171 & 1384.4 & 7.22 & -8.48 & 208 \\
\hline 13 & 1317.9 & 7.59 & -9.46 & 60 & 1359.5 & 7.36 & -8.80 & 73 \\
\hline 14 & 1292.2 & 7.74 & -9.81 & 65 & 1337.5 & 7.48 & -9.11 & 90 \\
\hline 15 & 1269.5 & 7.88 & -10.12 & 50 & 1307.3 & 7.65 & -9.48 & 155 \\
\hline 16 & 1222.6 & 8.18 & -10.85 & 163 & 1283.8 & 7.78 & -9.78 & 55 \\
\hline 17 & & & & & 1246.8 & 8.02 & -10.32 & 340 \\
\hline 18 & & & & & 1223.3 & 8.17 & -10.67 & 116 \\
\hline 19 & & & & & 1200.6 & 8.33 & -11.06 & 65 \\
\hline 20 & & & & & 1175.0 & 8.51 & -11.55 & 117 \\
\hline Purge & 1295.6 & 7.72 & -9.74 & 65 & & & & \\
\hline
\end{tabular}




\section{References}

Anderson AT (1968) Oxidation of the LaBlache Lake titaniferous magnetite deposit, Quebec. J Geol 76:528-547

Anderson DJ, Lindsley DH (1988) Internally consistent solution models for $\mathrm{Fe}-\mathrm{Mg}-\mathrm{Mn}-\mathrm{Ti}$ oxides: $\mathrm{Fe}-\mathrm{Ti}$ oxides. Am Mineral 73:714-726

Anovitz LM, Treiman AH, Essene EJ, Hemingway BS, Westrum Jr EF, Wall VJ, Burriel R, Bohlen SR (1985) The heat-capacity of ilmenite and phase equilibria in the system $\mathrm{Fe}-\mathrm{Ti}-\mathrm{O}$. Geochim Cosmochim Acta 49:2027-2040

Arculus RJ (1985) Oxidation status of the mantle: past and present. Ann Rev Earth Planet Sci 13:75-95

Arculus RJ, Delano JW (1981) Intrinsic oxygen fugacity measurements: techniques and results for spinels from upper mantle peridotites and megacryst assemblages. Geochim Cosmochim Acta 45:899-913

Buddington AF, Lindsley DH (1964) Iron-titanium oxide minerals and synthetic equivalents. J Petrol 5:310-357 (part 2)

Carmichael ISE (1967) The iron-titanium oxides of salic volcanic rocks and their associated ferromagnesian silicates. Contrib Mineral Petrol 14:36-64

Darken LS, Gurry RW (1945) The system iron-oxygen I. The wustite field and related equilibria. J Am Chem Soc 67:1398-1412

Des Marais DJ, Moore JG (1984) Carbon and its isotopes in midoceanic basaltic glasses. Earth Planet Sci Lett 69:43-57

Elliott WC, Grandstaff DE, Ulmer GC, Buntin T (1982) An intrinsic oxygen fugacity study of platinum-carbon associations in layered intrusions. Econ Geol 77:1493-1510

Ghiorso MS (1985) Chemical mass transfer in magmatic processes 1. thermodynamic relations and numerical algorithms. Contrib Mineral Petrol 90:107-120

Ghiorso MS, Carmichael ISE (1981) A fortran IV computer program for evaluating temperatures and oxygen fugacities from the compositions of coexisting iron-titanium oxides. Computers Geosci 7:123-129

Ghiorso MS, Carmichael ISE (1985) Chemical mass transfer in magmatic processes II. Applications in equilibrium crystallization, fractionation and assimilation. Contrib Mineral Petrol 90:121-141

Holmes RD, O'Neill HStC, Arculus RJ (1986) Standard Gibbs free energy of formation for $\mathrm{Cu}_{2} \mathrm{O}, \mathrm{NiO}, \mathrm{CoO}$, and $\mathrm{Fe}_{\mathrm{x}} \mathrm{O}$ : high resolution electrochemical measurements using zirconia solid electrolytes from 900-1400 K. Geochim Cosmochim Acta 50:2439-2452

Hunter RH, Sparks RSJ (1987) The differentiation of the Skaergaard intrusion. Contrib Mineral Petrol 95:451-461

Keil K, Fricker PE (1974) Baddeleyite $\left(\mathrm{ZrO}_{2}\right)$ in gabbroic rocks from Axel Heiberg island, Canadian Arctic Archipelago. Am Mineral 59:249-253

Kiukkola K, Wagner C (1957) Measurements on galvanic cells involving solid electrolytes. J Electrochem Soc 104:379-387

Lindsley DH (1976) Experimental studies of oxide minerals. In: D Rumble III (ed) Oxide minerals. Mineral Soc Am 61-84

Lindsley DH, Spencer KJ (1982) Fe-Ti oxide geothermemetry: reducing analyses of coexisting Ti-magnetite $(\mathrm{Mt})$ and ilmenite (Ilm). Trans Am Geophys Un 63:471

Loureiro D, Delano JW, Leblanc M, Dautria JM, Gurney JJ, Nixon PH (1989) Electrochemical determinations of the oxygen fugacity in equilibrium with mantle-derived ilmenite megacrysts at 1 bar. Contrib Mineral Petrol (in press)

Mattioli GS, Wood BJ (1988) Magnetite activities across the $\mathrm{MgAl}_{2} \mathrm{O}_{4}-\mathrm{Fe}_{3} \mathrm{O}_{4}$ spinel join, with application to thermobarometric estimates of upper mantle oxygen fugacity. Contrib Mineral Petrol 98:148-162

McBirney AR (1975) Differentiation of the Skaergaard intrusion. Nature 253:691-694
McMahon BM (1984) Petrologic redox equilibria in the Benfontein kimberlite sills and in the Allende meteorite, and the temperature-oxygen fugacity stability of kimberlitic ilmenite from the Monastery diatreme. PhD thesis Univ of Mass

Morse SA, Lindsley DH, Williams RJ (1980) Concerning intensive parameters in the Skaergaard intrusion. Am J Sci 280A:159 170

Norton D, Taylor HP (1979) Quantitative simulation of the hydrothermal systems of crystallizing magmas on the basis of transport theory and oxygen isotope data: an analysis of the Skaergaard intrusion. J Petrol 20:421-486 (part 3)

O'Neill HStC (1987) Quartz-fayalite-iron and quartz-fayalite-magnetite equilibria and the free energy of formation of fayalite $\left(\mathrm{Fe}_{2} \mathrm{SiO}_{4}\right)$ and magnetite $\left(\mathrm{Fe}_{3} \mathrm{O}_{4}\right)$. Am Mineral 72:67-75

O'Neill HStC, Wall VJ (1987) The olivine-orthopyroxene-spinel oxygen geobarometer, the nickel precipitation curve, and the oxygen fugacity of the Earth's upper mantle. J Petrol 28:1169-1191 (part 6)

Sato M (1971) Electrochemical measurements and control of oxygen fugacity and other gaseous fugacities with solid electrolyte systems. In: Ulmer GC (ed) Research techniques for high pressure and high temperature. Springer, Berlin Heidelberg New York, pp 43-99

Sato M (1976) Oxygen fugacity and other thermochemical parameters of Apollo 17 high-Ti basalts and their implication on the reduction mechanism. Proc Lunar Planet Sci Conf 7th:1323 1344

Sato M (1979) The driving mechanism of lunar pyroclastic eruptions inferred from the oxygen fugacity behavior of Apollo 17 orange glass. Proc Lunar Planet Sci Conf 10th:311-325

Sato M, Valenza M (1980) Oxygen fugacities of the layered series of the Skaergaard intrusion, East Greenland. Am J Sci 280A: $134-158$

Spencer KJ, Lindsley DH (1981) A solution model for coexisting iron-titanium oxides. Am Mineral 66:1189-1201

Stormer Jr JC (1983) The effect of recalculation on estimates of temperature and oxygen fugacity from analyses of multicomponent iron-titanium oxides. Am Mineral 68:586-594

Taylor Jr HP, Forester RW (1979) An oxygen and hydrogen isotope study of the Skaergaard intrusion and its country rocks: a description of a $55 \mathrm{~m}$.y. old fossil hydrothermal system. J Petrol 20:355-419 (part 3)

Ulmer GC, Grandstaff DE, Weiss D, Moats MA, Buntin TJ, Gold DP, Hatton CJ, Kadik A, Koseluk RA, Rosenhauer M (1987) The mantle redox state; an unfinished story? Geo Soc Am Spec Paper 215: 5-22

Vincent EA, Phillips R (1954) Iron-titanium oxide minerals in layered gabbros of the Skeargaard intrusion, East Greenland. Geochim Cosmochim Acta 6:1-26

Virgo D, Luth RW, Moats MA, Ulmer GC (1988) Constraints on the oxidation state of the mantle: An electrochemical and ${ }^{57} \mathrm{Fe}$ Mossbauer study of mantle-derived ilmenites. Geochim Cosmochim Acta 52:1781-1794

Wager LR, Brown GM (1967) Layered igneous rocks. Freeman, San Francisco, p 588

Wager LR, Deer WA (1939) Geological investigations in East Greenland. III. The petrology of the Skaergaard intrusion, Kangerdlugssuag, East Greenland. Medd Gronland 105:1-352

Wood BJ, Virgo D (1987) Oxidation state of the uppermantle: ferric-ferrous ratios in coexisting minerals from spinel therzolites. Geol Soc Am Progr Abstr p 896

Received August 1, 1988 / Accepted March 16, 1989

Editorial responsibility: T.C. Grove 